\title{
Late Cretaceous marine transgressions in Ecuador and northern Peru: a refined stratigraphic framework
}

\author{
Etienne Jaillard ${ }^{\mathrm{a}}$, Peter Bengtson ${ }^{\mathrm{b}}$ and Annie V. Dhondt $\mathrm{t}^{\mathrm{c}}$ \\ ${ }^{a}$ IRD-LGCA, Université de Grenoble, Maison des Géosciences, BP 53, F-38041 Grenoble cedex, \\ France; \\ or IRD-LMTG, Observatoire Midi-Pyrénées, 14 avenue Edourd Belin, F-31400 Toulouse, France; \\ E-mail: Etienne.Jaillard@ujf-grenoble.fr

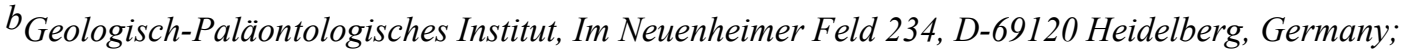 \\ E-mail: bengtson@uni-hd.de \\ ${ }^{c}$ Department of Palaeontology, Koninklijk Belgisch Instituut voor Natuurwetenschappen, Vautierstraat \\ 29, B-1000 Brussels, Belgium; \\ E-mail: Annie.Dhondt@naturalsciences.be
}

Received 9 January 2003; revised 3 August 2004; accepted XXX

\begin{abstract}
Study of ammonites and bivalves along selected sections on the Andean margin of northern Peru and Ecuador has made it possible to recognize correlatable marine transgressions and to propose a refined stratigraphic framework for the Upper Cretaceous of the region. Six maximum flooding events are recognized: latest Turonian-early Coniacian (major event), late Coniacian-early Santonian, late Santonian-early Campanian, mid Campanian-early late Campanian (major event), early Maastrichtian (major event), and terminal early Maastrichtian. Most of these events can be correlated with global eustatic sea-level rises, but their relative manifestations indicate that the Andean margin was already being deformed by the late Cretaceous "Peruvian" tectonic events. The onset of fine-grained clastic sedimentation in the Oriente and East-Peruvian basins in the mid Turonian-earliest Coniacian is taken as the first event of the "Peruvian" phase. The Campanian regional transgression in the Peruvian-Ecuadorian forearc zones concealed the "Peruvian" deformational event. The latter caused a palaeogeographic upheaval, indicated by the subsequent development of a NNE-trending forearc basin, which extended from Paita in northwestern Peru to northern Ecuador. In the forearc zones only short-lived transgressions are recorded in the late Campanian and early Maastrichtian as a result of nearly continuous tectonic activity. This culminated with a significant tectonic event in the late Maastrichtian, causing a widespread hiatus.
\end{abstract}

Keywords: Late Cretaceous; stratigraphy; ammonites; inoceramids; transgressions; Ecuador; Peru

\section{Introduction}

The active margin of western South America is marked by the development of the extensive Cretaceous Andean Basin, which encompassed large parts of Ecuador, Peru and central Bolivia. The late Turonian-Maastrichtian interval is a crucial period, which saw the onset of compressional deformation and uplift of the Andean margin followed by a marine regression in the Andean Basin (e.g. Steinmann, 1929; Jaillard et al., 2000).

During Albian-Campanian times, the depocenter of the Andean Basin was located in northern Peru. In this area, the Upper Cretaceous sedimentary successions are richly fossiliferous and the terminal Cretaceous regional regression occurred later than 
in other Andean areas. Consequently, the Late Cretaceous marine transgressions in this area are well recorded in the sedimentary succession.

Tectonic activity on the Andean margin began in the Late Cretaceous, and caused increasing uplift and erosion, particularly in the forearc and arc zones and in the western backarc areas (present-day coast and the western Cordillera). This may have obscured the global, synchronous eustatic signal, making reliable chronostratigraphic correlations across the Andes difficult. Although marine transgressions can be caused by tectonic subsidence, tectonic events, however, do not erase the eustatic signal; the sedimentary fill of the tectonically controlled Andean basins record these eustatic transgressions. In order to verify the eustatic origin of the transgressions, we discuss their geographical extent and compare them with coeval transgressions recorded in other regions in and around South America.

Although the stratigraphy of these areas has been studied since early in the last century, no detailed biostratigraphic work has been carried out in the past fifty years. We here review the palaeontological data and stratigraphic assignments, in the light of current palaeontological and biostratigraphic knowledge. However, the nature, evolution and age range of the South American macrofaunas remain poorly known, making accurate determinations and datings difficult. Nevertheless, precise dating of the maximum flooding events of marine transgressions, considered as time-lines, will make it possible to correlate the forearc and backarc deposits and hence the sedimentary and tectonic events across the Andean margin and, ultimately, to clarify the early evolution of the Andean margin.

For these reasons, we undertook a detailed stratigraphic study of the Upper Cretaceous of northern Peru and Ecuador. Here we present our results for the Coniacian-Maastrichtian succession based on study of macrofossils (mainly ammonites and inoceramid bivalves) collected from selected sections in eastern and southern Ecuador and northern Peru (Fig. 1). Numbers in brackets after species names are field codes denoting locality or horizon. Species mentioned in the literature without description or illustration or lacking precise locality data are not discussed in detail.

For the Turonian-Coniacian and Campanian-Maastrichtian stage boundaries we use the definitions based on the proposed GSSP (Global boundary Stratotype Section and Point) for the base of the Coniacian (Kauffman et al., 1996) and the ratified GSSP for the base of the Maastrichtian (Odin and Lamaurelle, 2001). The ConiacianSantonian and Santonian-Campanian stage boundaries have not yet been formally defined.

\section{Geological setting}

During the Cretaceous the Andean margin was submitted to continuous N- to NEward directed subduction. The Peruvian margin comprised from west to east: a narrow forearc zone; a still poorly known, mainly subaerial arc zone; and a wide backarc zone. The backarc zone comprised a subsiding basin in the west (West-Peruvian Trough, Fig. 1), which was separated from a moderately subsiding basin in the east (East-Peruvian Basin) by a positive area (Marañón Geanticline, Benavides-Cáceres, 1956; Wilson, 1963). In Ecuador, the eastern backarc zone, represented by the Oriente Basin, is separated from the significantly deformed western areas by the present-day Eastern Cordillera. There, intra-oceanic subduction is assumed to have occurred farther West, eventually causing accretion of oceanic terranes in the Late Cretaceous-Palaeogene (Reynaud et al., 1999; Kerr et al., 2002).

Recent geological studies and mapping of the forearc zones have shown that the Cretaceous sedimentary rocks belong to two distinct forearc basins of early Late Cretaceous and latest Cretaceous age, respectively (Jaillard et al., 1996; 1998; 1999). The deposits contained in these basins are separated by a regional unconformity (Jaillard et al., 1999), related to the "Peruvian" tectonic phase (Steinmann, 1929). Most 
of the data presented here concern the La Tortuga and La Mesa sections, south of Paita in northwestern Peru, and the "Celica-Lancones basin". The latter comprises an eastern arc succession (río Playas section) and a western succession that constitutes the cover of the Amotape-Tahuin Massif (Puyango-Cazaderos section) (Fig. 1, cf. Fig. 4). In addition, biostratigraphically significant macrofossils have been collected from numerous outcrops in northwestern Peru and southern Ecuador.

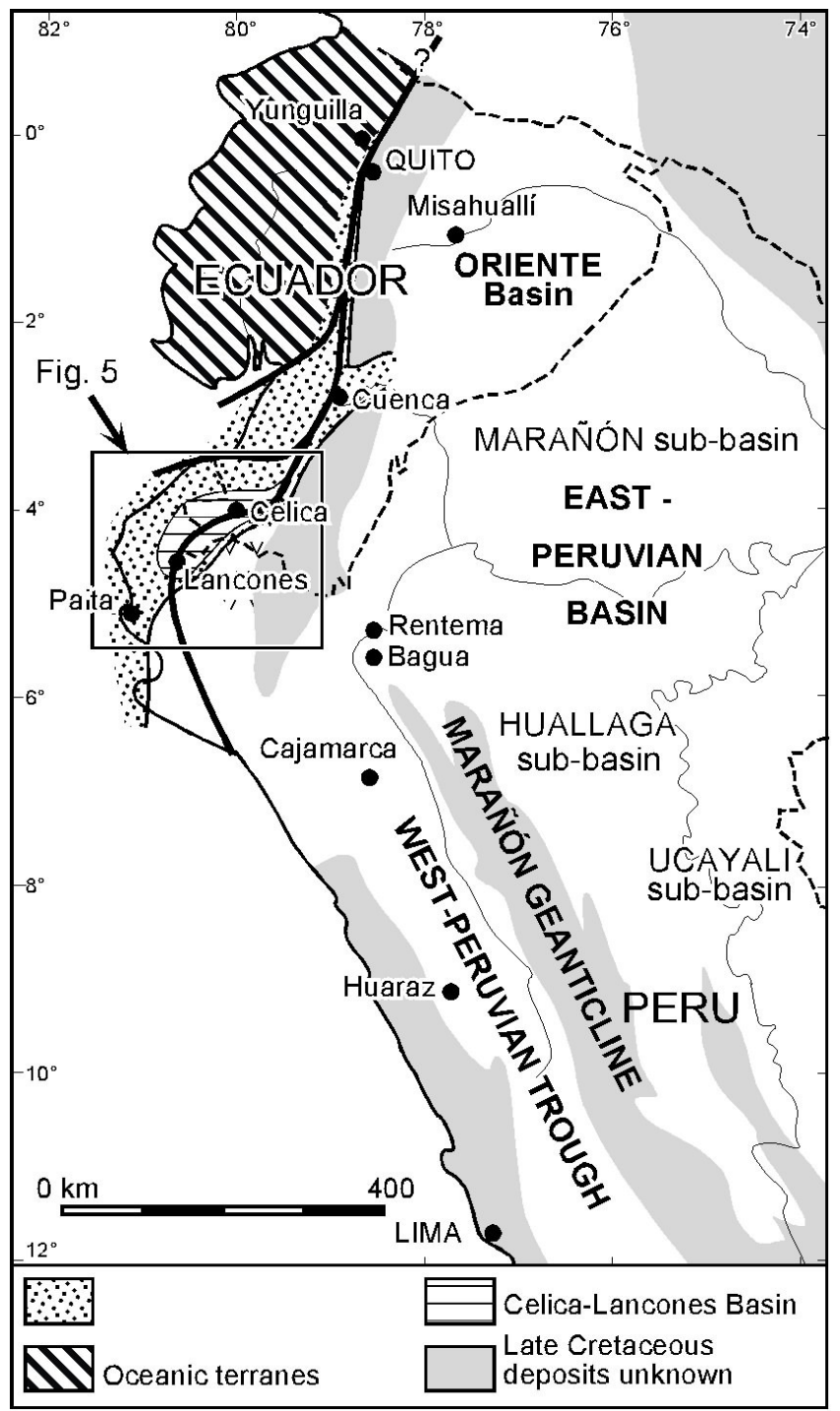

Fig. 1: General location map.

The West-Peruvian Trough received a thick pile of mainly marine sediments between Valanginian and Campanian times (Benavides-Cáceres, 1956; Robert, 2002). It comprises a strongly subsided zone centered around Huaraz, and a moderately subsided platform north of Cajamarca (Fig. 1). The trough does not extend northward into Ecuador. The sections studied here are located at Cajamarca and Pongo de Rentema, the latter situated on the boundary between the West-Peruvian Trough and the EastPeruvian Basin (the Bagua basin of Mourier et al., 1988).

The eastern basins of Ecuador (Oriente Basin) and Peru (Marañón Basin, Fig. 1) are characterized by marine deposits of Albian-Santonian age, followed by a dominantly non-marine succession of Maastrichtian-Eocene age (Tschopp, 1953; Mathalone and Montoya, 1995; Jaillard, 1997a). Data from these areas are based on the río Misahuallí (Ecuador) and Pongo de Rentema sections (Peru), from scattered outcrops, and from published and unpublished data related to petroleum exploration.

The forearc basins are characterized by active tectonics, by subsiding and mobile 
troughs and by open marine environments which continued locally until the end of the Eocene. By contrast, the eastern basins are marked by stable tectonic conditions, low subsidence rates, shallow restricted environments and by short-lived (although widespread) marine transgressions during the Santonian-Maastrichtian. The WestPeruvian Trough displays intermediate characteristics. Therefore, biostratigraphic correlation of the fossiliferous open-marine assemblages of the forearc zones with the restricted, mainly micropalaeontological assemblages of the eastern basins presents problems.

\section{Post-Turonian transgressions in the backarc basins}

The Turonian of the Andean Basin was characterized by sedimentation on a wide carbonate platform. This depositional regime was interrupted in the late Turonian-early Coniacian by a major transgression which marked the onset of extensive fine-grained terrigenous clastic sedimentation (Benavides-Cáceres, 1956; Wilson, 1963; Jaillard, 1994).

\subsection{Latest Turonian-early Coniacian maximum flooding event}

\subsubsection{Peru}

From the marls of the Chonta Formation of the northern part of the East-Peruvian Basin (Marañón Basin, Fig. 1), Kummel (1948), Rosenzweig (1953) and Ducloz and Rivera (1956) reported numerous specimens of the ammonite genus Tissotia, some Lenticeras, Buchiceras, Barroisiceras, and scarce Coilopoceras, Eulophoceras and Vascoceras. They considered this fauna to be of Turonian(?)-Coniacian age. Zegarra (1964) mentioned a fauna characterized by Barroisiceras sp. (among which B. cf. haberfellneri (von Hauer, 1866)) and Buchiceras bilobatum Hyatt, 1875, associated with Hauericeras sp., Peroniceras cf. moureti de Grossouvre, 1894, Lenticeras andii (Gabb, 1877), desmoceratids and tissotiids.

In the northern part of the West-Peruvian Trough (Cajamarca area), BenavidesCáceres (1956) defined the Buchiceras bilobatum Zone containing species of Barroisiceras, Solgerites, Forresteria, Tissotia, Heterotissotia and Buchiceras, traditionally a typical lower Coniacian assemblage (Bengtson, 1988). However, the recently proposed Global boundary Stratotype Section and Point (GSSP) for the base of the Coniacian (base of bed MK 47 in the Salzgitter-Salder Quarry in Lower Saxony, Germany; Kauffman et al., 1996) lies stratigraphically higher than the previously accepted stage boundary based on ammonites. The Buchiceras bilobatum Zone, at least in part, should therefore now be referred to the upper Turonian.

Extensive collections along the Pongo de Rentema section, on the boundary between the West- and East-Peruvian basins (Figs 1 and 2), have yielded the following ammonites and bivalves in situ, listed in stratigraphical order:

- from Turonian marls and limestones: Coilopoceratidae sp. (R.69), Mytiloides labiatus (von Schlotheim, 1813) (R.69), Kamerunoceras? sp. (R.70);

- from Coniacian shales: Paratissotia sp. (R.77), Texanites cf. vanhoepeni Klinger \& Kennedy, 1980 (R.77), Heterotissotia juv. (R.145), Lenticeras sp. (R.146), Metatissotia? sp. (R.152, R.121, R.124), Lenticeras andii (R.152) and Tissotiidae indet. (R.128, R.130, R.131). The bivalves Platyceramus cf. cycloides (Wegner, 1905) (R.152), Platyceramus sp. (96.R.156), Cordiceramus ex. gr. muelleri (Petrascheck, 1904) (R.156) in the lower part of the succession and Platyceramus cycloides (R.124) in the upper part suggest a Coniacian-Santonian age (Fig. 2).

In addition to these specimens, we have studied material collected by geologists of Petróleos del Perú - PetroPerú S.A. and Occidental Petroleum Company (Oxy) from the Pongo de Rentema section. This material has been calibrated with our data, although many of the PetroPerú and Oxy specimens appear to be derived from higher levels as a 
result of gravitational and/or river transport.

The late Turonian-early Coniacian transgression is associated with the onset of terrigenous clastic deposition.

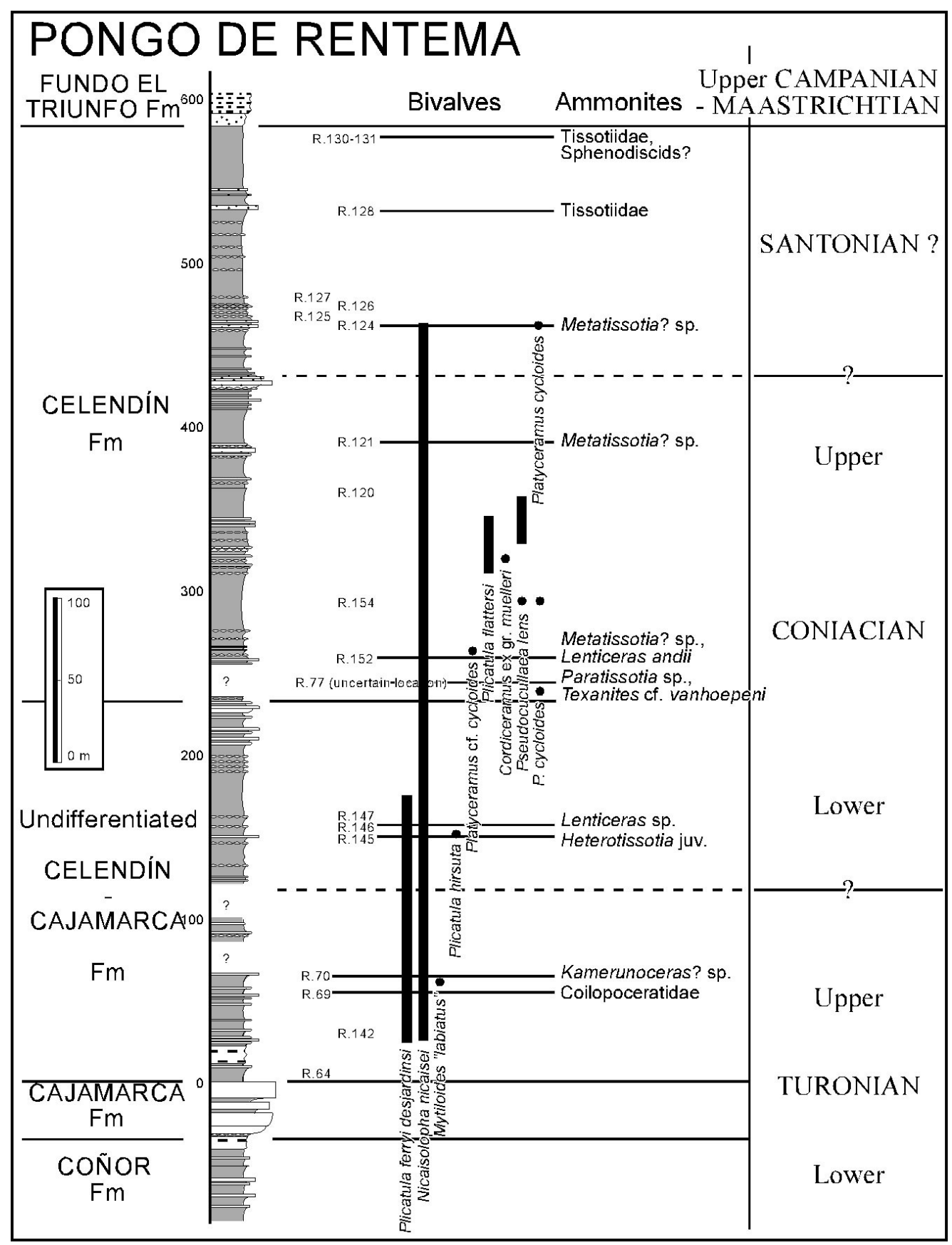

Fig. 2: Stratigraphic section at Pongo de Rentema (northern Peru) with ranges and occurrences of the main diagnostic taxa.

\subsubsection{Ecuador}

From the Oriente Basin (Fig. 3), Tschopp (1953) and Hobbs (1975) reported Peroniceras sp. (lower or middle Coniacian). In the northern part of the basin (Río Quijos), Monciardini et al. (1984) ascribed a 10-m-thick succession to the Coniacian on the basis of the foraminifers Archeoglobigerina aff. cretacea (d'Orbigny, 1840), Dicarinella primitiva (Dalbiez, 1955) and Marginotruncana ex gr. renziangusticarinata (Gandolfi, 1942).

A latest Turonian (in current terms; see above) marine transgression has also been identified in the río Misahuallí section (Jaillard, 1997a, Fig. 3). At the top of the upper Turonian M-2 limestones, transgressive calcareous beds yielded the inoceramid 
Mytiloides sp. and the ammonite Barroisiceras sp. (95.5). From a level $10 \mathrm{~m}$ above these occurrences, in marine shales representing the maximum flooding event, we collected Mytiloides sp. (94.39, 94.39a), Archeoglobigerina aff. cretacea, Dicarinella primitiva and Hedbergella planispira (Tappan, 1940) and the nannofossil

Marthasterites furcatus (Deflandre in Deflandre et Fert, 1954) (Jaillard, 1997a). The cooccurrence of Mytiloides sp. and Barroisiceras in this section indicates a latest Turonian age for the transgression. This dating is consistent with the occurrence of Dicarinella ex gr. hagni-concavata (Brotzen, 1934), Marginotruncana sigali (Reichel, 1949) and Whiteinella spp. in the transgressive beds disconformably overlying the M-2 limestones in the Mirador section (Jaillard, 1997a).

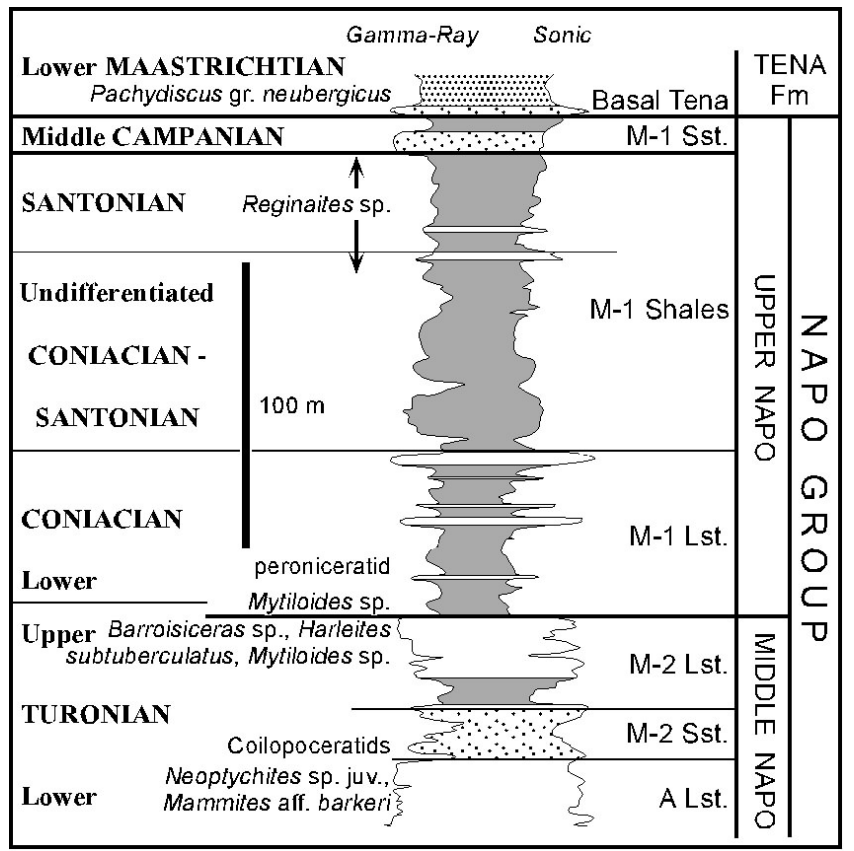

Fig. 3: Section and electric logs for the Oriente Basin (Ecuador), with stratigraphic occurrences of the main diagnostic taxa.

Farther north (río Quijos), from shales approximately $20 \mathrm{~m}$ above the M-2 Limestones, P. Baby (IRD) collected a loose impression of a peroniceratine ammonite $(96.13 \mathrm{~Eb})$, suggesting an early or mid Coniacian age.

\subsection{Late Coniacian-early Santonian maximum flooding event}

\subsubsection{Peru}

In the East-Peruvian Basin of northern Peru, Kummel (1948), Rosenzweig (1953) and Ducloz and Rivera (1956) found no evidence of Santonian. Zegarra (1964) mentioned the ammonite Texanites sp. and numerous specimens of Tissotia (T. cf. singewaldi Knechtel, 1947, T. cf. roscheni Knechtel, 1947, Tissotia nov. sp.) collected above the Barroisiceras-Buchiceras assemblage, indicating middle or upper Coniacian.

In the northern part of the West-Peruvian Trough (Cajamarca area), BenavidesCáceres (1956) defined the Lenticeras baltai Zone and described Bostrychoceras? sp., Desmophyllites gaudana (Forbes, 1846), Texanites hourcqi Collignon, 1948, Tissotia steinmanni Lisson, 1908, T. fourneli (Bayle, 1850), T. halli Knechtel, 1947 and Lenticeras lissoni (Knechtel, 1947). He considered this assemblage broadly Santonian in age, later referred by Bengtson (1988) to probably the early Santonian. However, ammonite systematics and international chronostratigraphic correlations around the Coniacian-Santonian boundary remain imprecise and even a late Coniacian age must be considered possible, especially in view of the fact that the genus Tissotia is not definitely known from post-Coniacian levels (Wright, 1996). 
A late Coniacian-early Santonian age for the middle part of the Celendín Formation s.s is supported by the appearance of the bivalves Platyceramus cycloides (R.124) of Santonian-early Maastrichtian age and Cordiceramus ex gr. muelleri (Fig. 2).

\subsubsection{Ecuador}

From the southern part of the Oriente Basin (Fig. 3), Hobbs (1975) mentioned a tissotiid ammonite. In the northern part of the basin (río Quijos), Monciardini et al. (1984) determined a Santonian foraminiferal association with Dicarinella concavata (Brotzen, 1934) (aff. asymetrica (Sigal, 1952)), D. cf. ventricosa (White, 1928), and several species of Marginotruncana in a 20-m-thick succession. In addition, detailed micropalaeontological studies (mainly of palynomorphs) have indicated a Santonian age for the upper part of the upper Napo Formation (e.g. Robertson Research, 1988; see review in Jaillard, 1997a).

In southeastern Ecuador (Santiago-Morona road), an isolated outcrop of marls and limestones (94.76) yielded a Reginaites sp. (Santonian-lower Campanian; Klinger and Kennedy, 1980; Wright, 1996) associated with Plicatula ferryi Coquand, 1862, Pycnodonte flicki Pervinquière, 1912, and Coniacian-Santonian echinoids, which taken together suggest a Santonian age. Although well-exposed field sections are lacking, the occurrence of these species and the micropalaeontological data collected from wells (review in Jaillard, 1997a) suggest that the late Coniacian-early Santonian transgression reached part of the Oriente Basin.

\subsection{Late Santonian-early Campanian maximum flooding event}

In the Pongo de Rentema section (Fig. 2), we have found no ammonites of Santonian or younger age in situ, although the highest levels exposed of the Celendín Formation have yielded fragments of smooth, flat sphenodiscids (R.130, R.131; Fig. 2) together with "untypical" tissotiids, which seems to indicate a faunal change. A Submortoniceras sp. (349) collected by PetroPerú geologists from $5 \mathrm{~m}$ above their last tissotiid specimen but some $30 \mathrm{~m}$ below our definite last occurrence of this taxon (R.128) may derive from stratigraphically higher beds exposed in the vicinity. Similarly, a sphenodiscid (13) collected by Oxy geologists from near the top of the marine sequence may also have come from higher levels.

In the Oriente Basin of Ecuador, the upper part of the M-1 Shales (upper Napo Formation, Fig. 3) locally comprises marine shelf shales and fine-grained sandstones, individualized as a distinct sedimentary body (Rivadeneira et al., 1995). In the central part of the basin, this unit yielded an association of palynomorphs, dinocysts and few nannofossils, which indicate a late Santonian to earliest Campanian age (Raynaud et al., 1993; Robertson Research, 1997). As these beds are separated from the over- and underlying beds by unconformities (Raynaud et al., 1993; Robertson Research, 1997), they probably represent transgressive to maximum flooding deposits. However, since the contact with the overlying sandstones is erosional, these deposits are only locally known.

\subsection{Mid to early late Campanian maximum flooding event}

In the eastern basins, massive transgressive sandstones (lower Vivian Formation of the Marañón Basin, M-1 Sandstones of Ecuador, Fig. 3) are overlain by a thin layer of marine shales which have yielded palynomorphs suggesting the middle part of the Campanian (in Peru: Salas, 1991; Mathalone and Montoya, 1995; in Ecuador: Mills, 1972; Robertson Research, 1988; 1997; Raynaud et al., 1993; see review in Jaillard, 1997a).

This transgression is well manifested in the Bagua area of northern Peru 
(Mourier et al., 1988), where the upper levels of the Celendín Formation contain the ammonites Manambolites sp. and Libycoceras sp. (abundant), associated with Menabites sp., Submortoniceras sp. and Pachydiscus sp. juv. (Bengtson, 1988), the latter taxon now reassigned to Menuites sp. Collecting by J. Jacay (Univ. San Marcos, Lima) in the Bagua Basin (in 1994) yielded a very similar fauna from Gallo Cantana, ca. $20 \mathrm{~km}$ south of Bagua (Fig. 1).

\subsection{Early Maastrichtian maximum flooding event}

In the eastern basins of Peru and Ecuador, thin marine layers representing an early Maastrichtian marine transgression have long been recognized. From the Cachiyacu Formation of Peru (Fig. 10), a Sphenodiscus sp. (Rodriguez and Chalco, 1975), an undetermined ammonite (Vargas, 1988) and early Maastrichtian microfossils (Gutierrez, 1975; Müller and Aliaga, 1981) have been reported. This unit is traditionally referred to the early Maastrichtian (Kummel, 1948; Salas, 1991; Mathalone and Montoya, 1995). Marine deposits of comparable lithology and faunal content have been described from the East-Peruvian Basin of central (Koch and Blissenbach, 1962; Robertson Research, 1990) and southern Peru (Dávila and Ponce de León, 1971; Soto, 1982) and from the Altiplano of southern Peru (Jaillard et al., 1993) and Bolivia (Sempéré et al., 1997).

The Tena Formation of the Oriente Basin (Ecuador, Figs. 3 and 10) has locally yielded the planktonic foraminifers Globotruncana cf. lapparenti Brotzen, 1936, Rugoglobigerina cf. rugosa (Plummer, 1926) (Sigal, 1969; Mills, 1972; Bristow and Hoffstetter, 1977), Globotruncana aegyptica Nakkady, 1950 and G. plummerae (Gandolfi, 1955) (Whittaker and Hodgkinson, 1979), suggesting the upper part of the lower Maastrichtian. More recently, detailed studies of pollen and dinoflagellates led Raynaud et al. (1993) to ascribe the basal part of the Tena Formation (Basal Tena unit) to the lower Maastrichtian.

Finally, along the Santiago-Morona road in southern Ecuador $(8.3 \mathrm{~km}$ east of the río Yaupi), we collected two ammonites from the base of the Tena Formation, identified as Pachydiscus ex gr. neubergicus of early Maastrichtian age.

Marine bivalves and unidentifiable large ammonites have been reported from shelf deposits of the southern part of the subandean zone of Ecuador ("Limón Flysch"), dated with Maastrichtian foraminifers (Faucher et al., 1971; Bristow and Hoffstetter, 1977). These deposits may have been deposited in an embayment of the forearc zone, connected to the eastern "Oriente" Basin.

Thus, the early Maastrichtian maximum flooding event appears to have been a major marine transgression in the eastern part of the Andean Basin.

\section{Post-Turonian transgressions in the forearc basins}

The stratigraphy of the forearc zones of northern Peru and southern Ecuador has been studied by Sigal (1969), Kennerley (1973) and Bristow and Hoffstetter (1977) in southwestern Ecuador; and Iddings and Olsson (1928), Olsson (1934, 1944), Fisher (1956), Reyes and Caldas (1987) and Reyes and Vergara (1987) in northwestern Peru. The forearc zone comprises two successive sedimentary basins of Cretaceous age, separated by a regional unconformity related to the "Peruvian" tectonic phase (Jaillard et al., 1996; 1999).

The "Celica-Lancones basin" is a tectonically active Albian-Coniacian trough infilled mainly by turbidites. The basin is located in northwestern Peru and southwestern Ecuador, between a volcanic arc to the east and southeast and the Palaeozoic Amotape-Tahuin massif to the west and northwest (Fig. 4). Therefore, the western succession constitutes the sedimentary cover of the Amotape-Tahuin Massif, whereas the eastern succession comprises volcanic-arc rocks and related volcaniclastic 
sediments of probably Albian age.

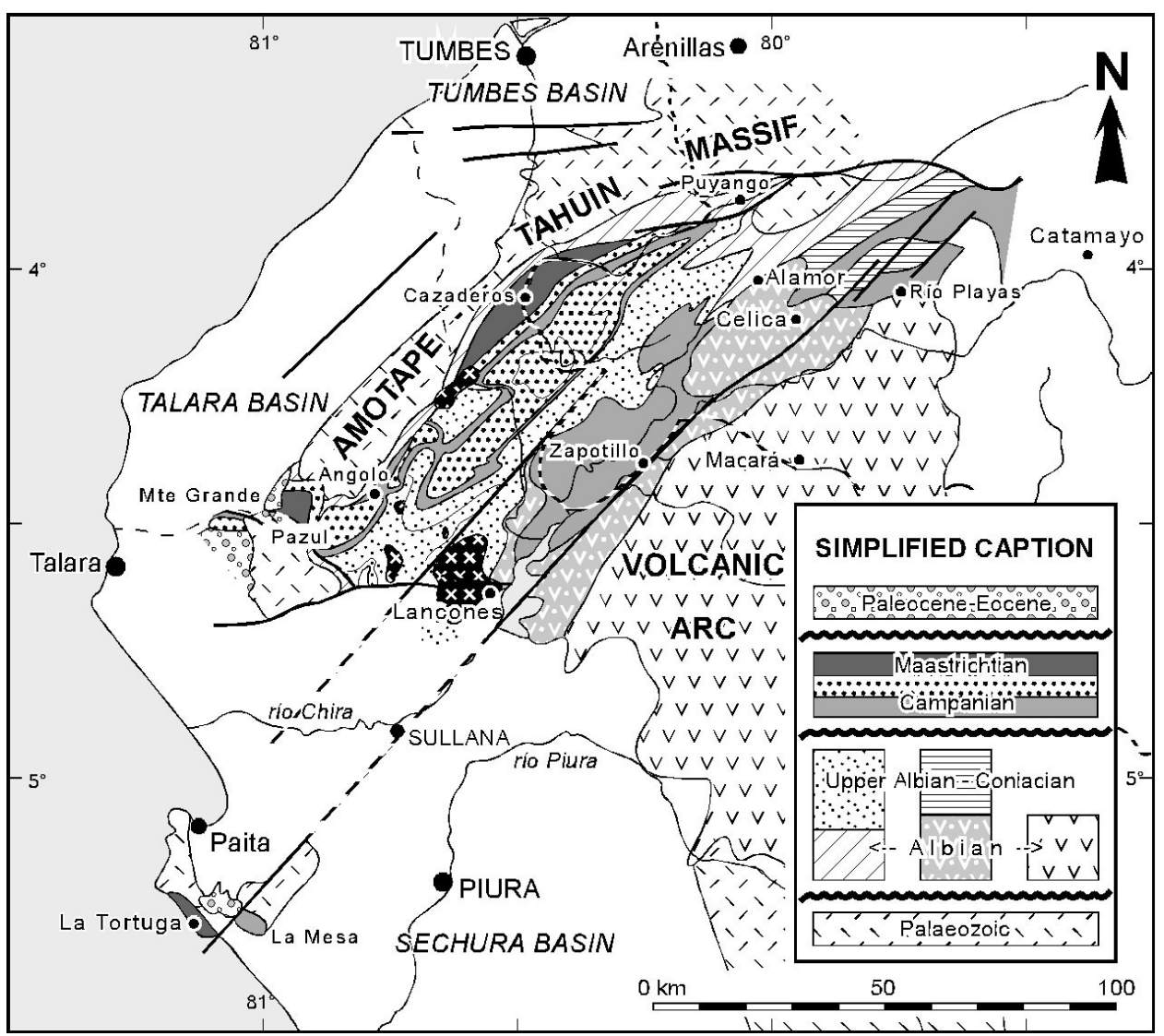

Fig. 4: Geological sketch map of the Paita and Celica-Lancones areas, with location of the main sections and localities cited in the text (the Talara, Tumbes and Sechura Basins are Tertiary Basins).

The sediments of the "Celica-Lancones basin" are disconformably overlain by the NNE-trending "Paita-Yunguilla forearc basin" (formerly included in the "CelicaLancones basin"), the Campanian-Maastrichtian sediments of which onlap onto the western Amotape-Tahuin Massif and the eastern volcanic arc. The basin extends into northern Peru to the South and western Ecuador to the North. The Campanian transgressive sediments of the basin rest disconformably on Palaeozoic rocks (Paita area), on deformed Albian and Upper Cretaceous rocks ("Celica-Lancones basin"), and on deformed, accreted oceanic rocks of Cretaceous age (western Cordillera of Ecuador). It is to be expected, therefore, that the tectonic activity disturbed the eustatic signal in these areas.

\subsection{Latest Turonian-Coniacian maximum flooding events}

The youngest fossils previously reported from the "Celica-Lancones basin" are the latest Turonian ammonites cf. Barroisiceras haberfellneri (Petersen, 1949) and Barroisiceras sp. (Reyes and Vergara, 1987) and a "Senonian" microfauna (Weiss, 1955) found in drill-holes, without precise stratigraphic location. Near Angolo in northern Peru we collected a loose impression of Protexanites cf. cycni (van Hoepen, 1965) (00.A.4Eb), a species referred to the early Coniacian by Klinger and Kennedy (1980). Thus, these faunas apparently belong to the latest Turonian-early Coniacian transgression in this turbiditic trough. 
Santonian deposits appear to be absent, probably as a result of deformation and erosion related to the "Peruvian" tectonic phase, which separates the evolution of the "Celica-Lancones" and "Paita-Yunguilla" basins (Fig. 5).

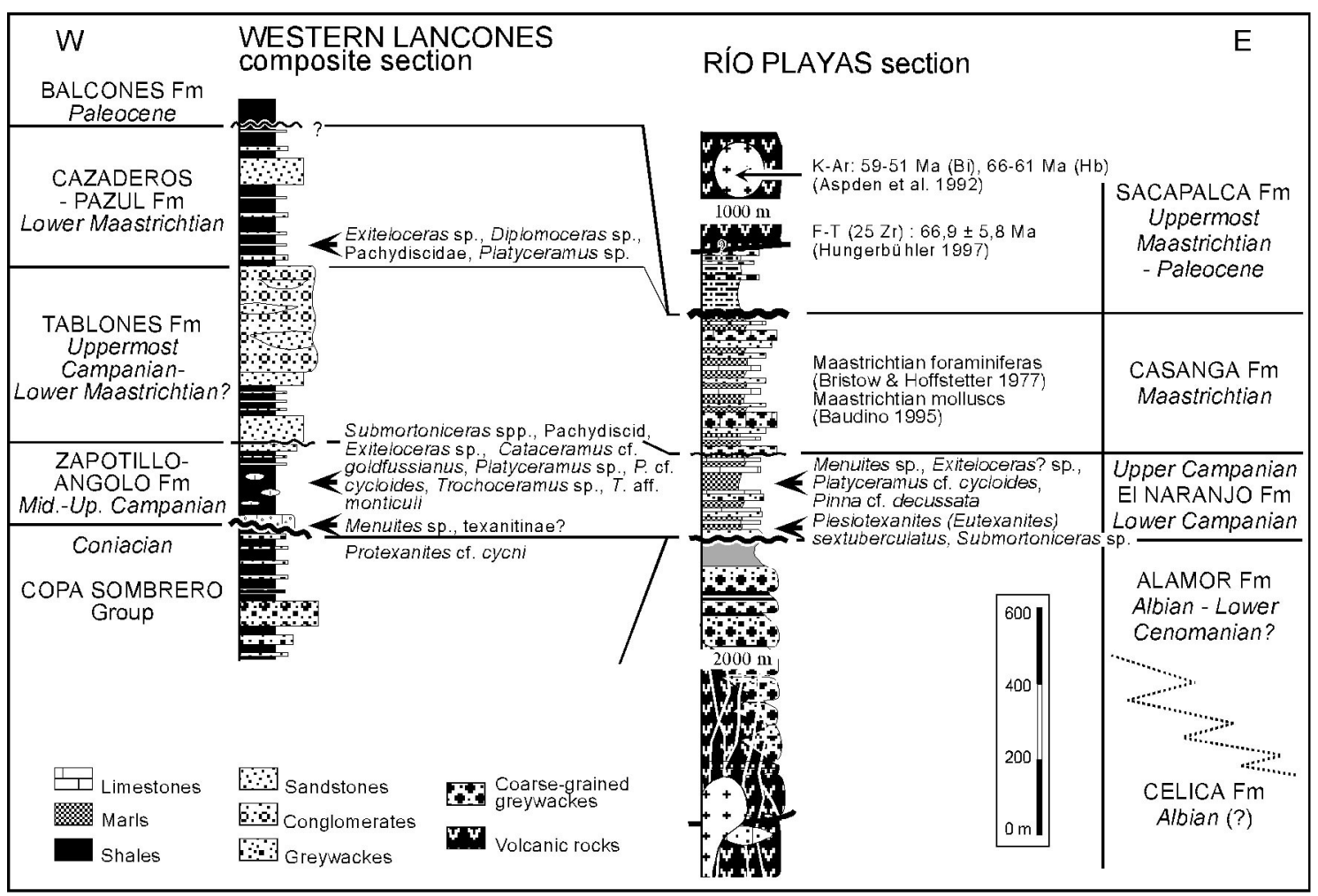

Fig. 5: Sections in the western (Puyango-Cazaderos) and eastern (Río Playas) parts of the "Celica-Lancones basin" in southern Ecuador (Fig. 4), with location of the main diagnostic taxa.

\subsection{Late Santonian-early Campanian maximum flooding event}

In the "Celica-Lancones basin", east of the Celica area (río Playas section), volcanic and volcaniclastic rocks of the Albian(?) magmatic arc are unconformably overlain by marine marls, shales and sandstones of the El Naranjo Formation (Fig. 5). The basal, transgressive part of these beds have yielded Plesiotexanites (Eutexanites) sextuberculatus Klinger \& Kennedy, 1980 (PO.114) and Submortoniceras sp. (96.1), suggesting an early Campanian age (Fig. 5). Associated bivalves (Trigonarca sp., Panopea sp., Pseudocucullaea lens Solger, 1903), and a few diagnostic nannofossils (Micula decussata Vekshina, 1959, Quadrum gartneri Prins \& Perch-Nielsen, 1977) are consistent with this age (Jaillard et al., 1996; Pérez and Reyes, 1996; Bengtson and Jaillard, 1997). Since these early Campanian marine beds are only recorded in this area, a tectonic origin for this localized transgression is probable.

\subsection{Mid to late Campanian transgression}

\subsubsection{Paita area}

The La Mesa section, southeast of Paita (Fig. 4), comprises three lithologic units (Fig. 6). The lower unit consists of transgressive shales, sandstones and limestones with ammonites of the genus Coahuilites (95.LM.7) indicating an age not older than late Campanian. The bivalves Ambigostrea villei (Coquand, 1862) (95.LM.1, 95.LM.5, 95.LM.6, 95.LM.26, 95.LT.4, 97.17) and Plicatula harrisiana Olsson, 1934 (95.LM.5, 97.17) indicate the Campanian-Maastrichtian interval.

The middle unit is represented by massive rudist- (radiolitids) and gastropodbearing shelf limestones, lacking diagnostic faunas. 
The upper unit consists of marls intercalated with limestone and sandstone beds, the lower part of which yielded Nostoceras sp. (95.LM.26) and Libycoceras sp.

(95.LM.26) as well as other sphenodiscid ammonites. The genus Nostoceras indicates a late Campanian age, a dating supported by the associated bivalve fauna (e.g., Plicatula harrisiana (97.17), Cataceramus aff. goldfussianus $(97.17,97.19 \mathrm{~Eb}$, PO.467) and the rudists belonging to the genera Biradiolites, Radiolites and Praebarretia) (Fig. 6).

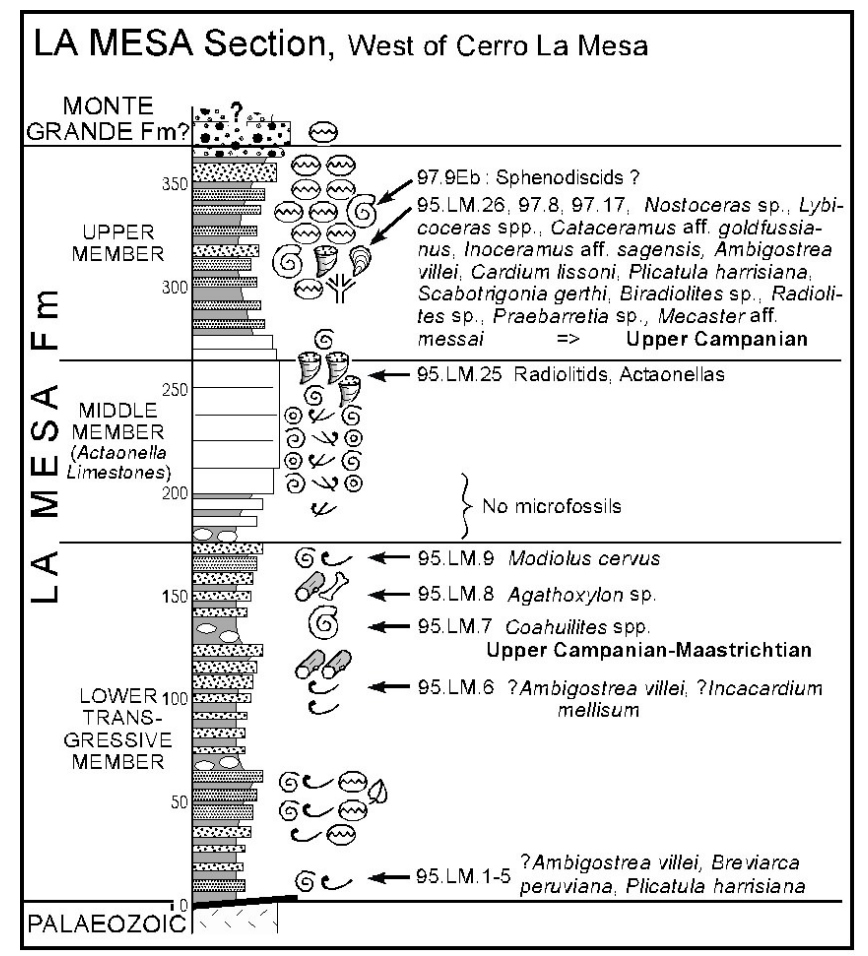

Fig. 6: Section of the La Mesa Formation in the Paita area of northwestern Peru, with location of diagnostic taxa.

\subsubsection{Celica-Lancones area}

In the Río Playas section, the fine-grained marls of the upper El Naranjo Formation reflect a new widespread marine transgression (Fig. 5). These beds have yielded the ammonites Menuites sp. (PO.19) and Exiteloceras? sp. (PO.19, PO.98) of Campanian age, associated with the Santonian-early Maastrichtian Platyceramus cf. cycloides (PO.261) and with microfossil assemblages (radiolarians, foraminifers, nannofossils) of late Campanian to Maastrichtian age (Jaillard et al., 1996; 1999).

In the central (Zapotillo, Lancones) and western parts (Angolo) of the CelicaLancones area, the early Late Cretaceous turbidites are overlain unconformably by black shales with limestone nodules and arkosic beds (Zapotillo Formation of Ecuador, Angolo Formation of Peru). These yielded a pachydiscid ammonite (00.A.05Eb) and Submortoniceras sp. $(96.4,96.5,97$. Ce.45), which indicate an age between late Santonian and mid Campanian. At Puyango (Ecuador), transgressive limestones resting on deformed Albian limestones have yielded a poorly preserved texanitinae? (95.30) and a Menuites sp. (PO.464Eb) collected loose. In the Monte Grande area in Peru, in a fault-bounded outcrop of shales ascribed to the Angolo Formation, we collected Exiteloceras sp. (95.MG.2) of Campanian age.

In the entire area, the Zapotillo and Angolo formations are characterized by the large inoceramid Platyceramus sp. (96.4, 97.19, 97.20, 99.A.19Eb, 99.A.20Eb, 99.A.22Eb, 00.A.08Eb, 00.A.18, 00.A.19, 00.A.20) and P. cf. cycloides (96.X) of Santonian-early Maastrichtian age, associated with scarcer Trochoceramus sp. (97.20) (latest Campanian-middle Maastrichtian), Trochoceramus aff. monticuli (Fugger \& Kastner, 1885) (96.X) (latest Campanian-early Maastrichtian) and Cataceramus cf. goldfussianus (d'Orbigny, 1847) (97.19Eb) (late Campanian). 
As a whole, this assemblage suggests a mid to late Campanian age (Fig. 5).

\subsubsection{Western Ecuador}

In the western Cordillera of central Ecuador, the Maastrichtian Yunguilla "Flysch" locally contain interbeds of calciturbidites (San Juan Limestones), which are dated as Campanian to early Maastrichtian (Thalmann, 1946; Kehrer and Kehrer, 1969). Part of the Yunguilla Formation may be coeval with the middle to late Campanian transgression.

\subsection{Early to mid Maastrichtian transgressions}

\subsubsection{Paita area}

The La Tortuga section, south of Paita (Fig. 4), comprises two formations. The La Tortuga Formation consists of approximately $4000 \mathrm{~m}$ of red breccias, which include a shaly interval representing a marine transgression (La Tortuga Beds of Olsson 1944, Middle Unit in Fig. 7). Further northwest, the Cenizo Formation consists of disconformable coarse-grained sandstones and subordinate conglomerates. These rocks rest directly on Palaeozoic rocks.

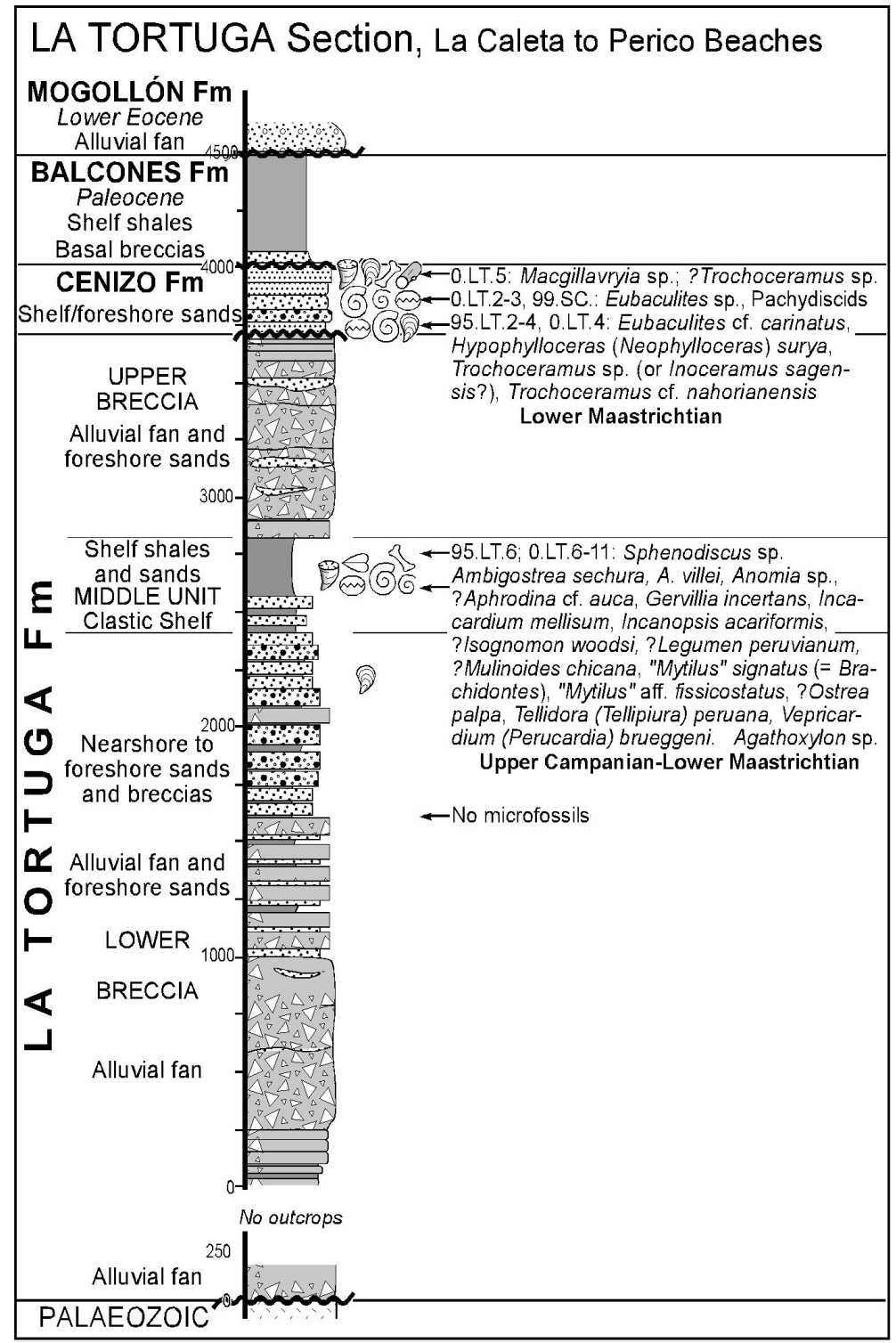

Fig. 7: Section of the La Tortuga and Cenizo formations in the Paita area of northwestern Peru, with location of diagnostic taxa. 
The Middle Unit of the La Tortuga Formation has yielded Sphenodiscus sp. (00.LT.9) and numerous bivalves, ascribed to the Campanian-Maastrichtian boundary interval (Fig. 7).

The La Tortuga upper breccias are capped by transgressive, fossiliferous yellow sandstones (Baculites Sandstones of Olsson, 1944, lower Cenizo Formation in Fig. 7 and 8), which have yielded numerous Eubaculites cf. carinatus (Morton, 1834) (95.LT.2) and one Hypophylloceras (Neophylloceras) surya (Forbes, 1846) (95.LT.2) of Maastrichtian age (Bengtson and Jaillard, 1997), probably early Maastrichtian (cf. Courville and Odin, 2001). Associated with these ammonites there are numerous wellpreserved bivalves, among which Trochoceramus cf. nahorianensis Kociubynskij, 1968 (95.LT.2) indicates a late Campanian to early Maastrichtian age (Dhondt and Jaillard, in press). Sample 00.LT.4 from the same unit might be either Inoceramus sagensis Owen, 1852 of Campanian age, or more probably, a Trochoceramus sp., thus indicating a prelate Maastrichtian age (Walaszczyk et al., 2001; Walaszczyk et al., 2002a, 2002b).

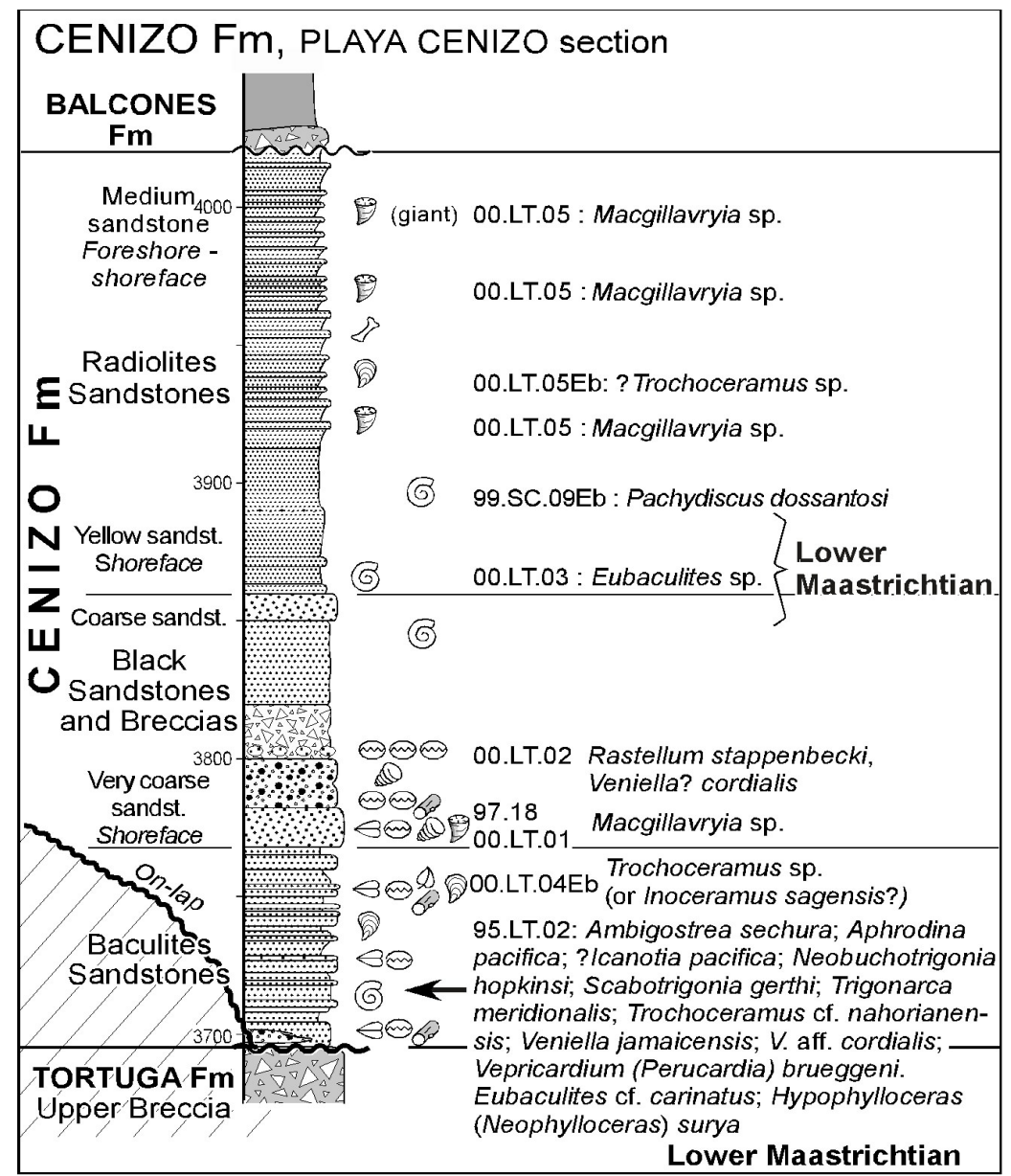

Fig. 8: Section of the Cenizo Formation in the Paita area of northwestern Peru, with location of diagnostic taxa.

The upper part of the Cenizo Formation (Radiolites Sandstones of Olsson, 1944) overlies dark-coloured conglomerates. Its lower part yielded Pachydiscus cf. epiplectus (Redtenbacher, 1873) (99.SC.3), P. dossantosi (Maury, 1930) (99.SC.9Eb) and Eubaculites sp. (00.LT.3) suggesting an early Maastrichtian age. Bivalves include the inoceramid Trochoceramus? sp. and numerous rudists belonging to the genus Macgillavryia. The middle part of the Cenizo Formation thus seems to be early Maastrichtian in age (Fig. 8).

According to these data, the older transgression (middle La Tortuga Fm) can be dated as late Campanian, and the succeding ones (lower and middle parts of Cenizo Fm) as early Maastrichtian. 


\subsubsection{Celica-Lancones area}

The Campanian Zapotillo and Angolo Formations are overlain by thick, coarsegrained conglomerates (Tablones Formation), in turn overlain by shales with limestone nodules and intercalations of quartz-rich, medium-grained turbidites (Cazaderos Formation in Ecuador, Pazul Formation in Peru, Fig. 5). In the western part of the area, these beds locally cover directly the Albian transgressive beds.

In the Cazaderos area (Ecuador), the Cazaderos Formation has yielded Diplomoceras sp. (95.33, PO.482), Exiteloceras sp. (PO.482), and an unidentifiable large pachydiscid $(95.40 \mathrm{~Eb})$ collected loose. In the same area, we collected Platyceramus sp. (PO.482, 99.A.11Eb) of Coniacian-early Maastrichtian age. This fauna and the stratigraphic relationships are consistent with a late Campanian-early Maastrichtian age.

\subsubsection{Western Ecuador}

In the Western Cordillera of central Ecuador (Fig. 1), the shales and turbidites of the Yunguilla Formation s.s. are dated with foraminifers as Maastrichtian (Thalmann, 1946; Sigal, 1969; Bristow and Hoffstetter, 1977; Pratt et al., 1998).

In the Western Cordillera, at $1^{\circ} 45$ 'S (near Huangupud), we collected the ammonites Exiteloceras sp. (99.G.74, 99.G.75) of Campanian age, and Hypophylloceras (Neophylloceras) sp. (99.G.75), comparable to H. (N.) surya from the lower El Cenizo Formation of northern Peru (see above). This association supports a late Campanian-early Maastrichtian age for the Yunguilla Formation.

In the Cuenca area (Fig. 1), the ammonites Sphenodiscus peruvianus Gerth, 1928 and Solenoceras sp. indicate an early Maastrichtian age for part of the Yunguilla Formation (Howarth, in Bristow and Hoffstetter, 1977; Pratt et al., 1998). In that region, a few kilometres SSE of Azogues, we collected a fragment of a Glyptoxoceras sp. (Santonian-Maastrichtian; Wright, 1996) or Neoglyptoxoceras sp. (lower-middle Campanian; Wright, 1996). $12 \mathrm{~km}$ ENE of Cuenca (El Descanso), we collected a Diplomoceras sp. (late Campanian-Maastrichtian; Küchler and Odin, 2001) (02.C.52), and two fragments (02.C.53) of Glyptoxoceras sp. or Neoglyptoxoceras sp.

According to these data, the Yunguilla Formation is most probably of late Campanian to early Maastrichtian age, and therefore coeval with the marine transgressions recognized in the Paita and Celica-Lancones areas.

\section{Correlations and tectonic implications}

Ages for the maximum flooding events are those applied to European basins as determined by Hardenbol et al. (1998), who also revised the relative sea-level maxima of Haq et al. (1987).

\subsection{Turonian-Coniacian}

A latest Turonian to early Coniacian maximum flooding event is clearly manifested in the backarc basins on the basis of data from the río Misahuallí and Rentema sections. Because of late Albian and Santonian deformations, the event is poorly expressed in the forearc zones.

This latest Turonian-early Coniacian maximum flooding event is poorly documented in the Andean areas, although Coniacian marine faunas are widely known. A significant maximum flooding event is mentioned by Haq et al. (1987) and Hardenbol et al. (1998) near the Turonian-Coniacian boundary (89-88.5 Ma), which fits well with our data (Fig. 9).

The end of the carbonate shelf sedimentation and the beginning of the finegrained clastic sedimentation is dated as latest Turonian-earliest Coniacian in Ecuador 
(Misahuallí) and as late Turonian in the Rentema area in Peru. This change in sedimentation has been interpreted as the beginning of the "Peruvian" tectonic phase (Jaillard, 1994; Sempéré, 1994).

\subsection{Santonian}

A Santonian maximum flooding event is locally manifested in the eastern basins of Ecuador and northern Peru. According to the faunas collected at Pongo de Rentema, it seems to be of late Coniacian-early Santonian age. No Santonian maximum flooding event is known to have occurred in the forearc zones of northern Peru and Ecuador but an early Santonian transgression has been identified in the forearc zone of southern Peru (Vicente, 1981; Jaillard, 1994). Transgressions or high sea-level periods of Santonian age are known in Colombia from the upper Magdalena Basin (Vergara, 1997) and the eastern basin (Guerrero and Sarmiento, 1996), and in Venezuela (Helenes et al., 1998; Helenes and Somoza, 1999).

The earliest Santonian age of the eustatic maximum flooding (ca. 86-85 Ma), quoted by Haq et al. (1987) and Hardenbol et al. (1998), is consistent with our data (Fig. 9). Because of the uplift during the "Peruvian" tectonic phase, the middle Santonian to early late Santonian maximum floodings mentioned by Haq et al. (1987) and Hardenbol et al. (1998) are unknown on the Andean margin of northern Peru and Ecuador.

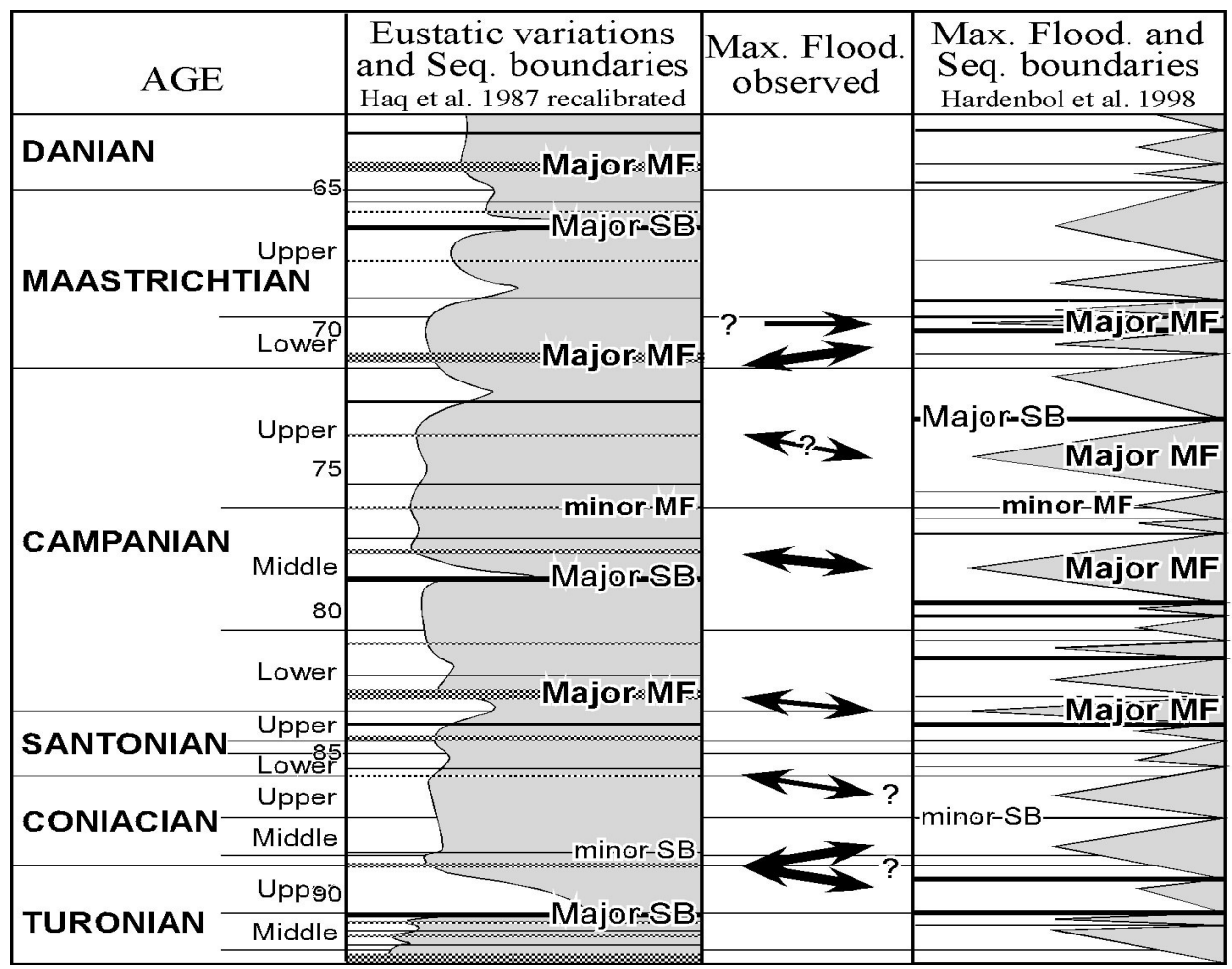

Fig. 9: Comparison between marine transgressions recognized in northern Peru and Ecuador and eustatic sea-level fluctuations identified by Haq et al. (1987 [recalibrated by Hardenbol et al., 1998]) and Hardenbol et al. (1998).

\subsection{Campanian}

A late Santonian-early Campanian maximum flooding event has been recognized only in the eastern part of the Celica-Lancones area and locally in the central part of the Oriente Basin of Ecuador (upper part of the M-1 Shales, below the M-1 Sandstones). In the Celica-Lancones area, it overlies unconformably volcanic rocks deformed by the mid and Late Cretaceous tectonic events. In the Oriente Basin it follows a depositional break comprising part of the Santonian (Raynaud et al., 1993; Robertson Research, 
1997). This late Santonian-early Campanian marine transgression was probably enhanced by tectonic subsidence, and seems to represent the first stage of the regional Campanian transgression that conceals the "Peruvian" deformations.

An early Campanian maximum flooding event is locally known, for example, from the eastern basin of northern Colombia (San Antonio Formation, Guerrero and Sarmiento, 1996) and the eastern Gulf Coastal Plain of North America (Mancini et al., 1996), but has not been identified in Venezuela (Helenes et al., 1999; Helenes and Somoza, 1999). This transgression might correspond to the major transgression identified by Haq et al. (1987, recalibrated by Hardenbol et al., 1998) and Hardenbol et al. (1998) near 83.5-83 Ma (Fig. 9). The fact that this major transgression is only locally manifested indicates that the Andean margin was already uplifted and deformed by the "Peruvian" deformations.

The mid Campanian to early late Campanian transgression was a major event that definitely concealed the "Peruvian" deformations. According to available data, this transgression is manifested in the eastern basins of Ecuador (M-1 Sandstones) and Peru (lower Vivian Formation) and in the forearc zones of northwestern Peru (La Mesa Formation), and southwestern Ecuador (upper El Naranjo Formation). Further south, thin marine layers containing selachians, scarce bivalves and charophytes have been correlated with the mid Campanian to early late Campanian transgression (Jaillard et al., 1993). In the forearc zones, this widespread transgression seems to have been characterized by the deposition of open-marine shelf limestones. Because emergence occurred after the early Santonian at Pongo de Rentema (see also Bengtson, 1988), the age of the "Peruvian" tectonic phase would be bracketed between mid Santonian and mid Campanian times.

The mid to early late Campanian transgression is known in the whole EastPacific area, from the Antarctic Peninsula (Askin et al., 1991) and Argentina (Lagarreta et al., 1989; Barrio, 1990) to Colombia and Venezuela (Barrio and Coffield, 1992; Guerrero and Sarmiento, 1996; Vergara, 1997, Helenes et al., 1998) and Central and North America (e.g. Gill and Cobban, 1973; Molenaar and Rice, 1989; Michaud et al., 1992). It is also manifested in the South Atlantic basins, for example in the Sergipe Basin (Bengtson et al., 1996) and the Pernambuco-Paraíba Basin (Muniz, 1993). Because the "mid" Campanian maximum flooding event reached the tectonically stable eastern basins of the Andean margin, it probably coincides with a significant eustatic sea level rise. According to Haq et al. (1987) and Hardenbol et al. (1998), mid and late Campanian times were marked by a high average sea level and by three sea-level rises. As the late mid Campanian (ca. $78 \mathrm{Ma}$ ) and late Campanian (ca. $73.5 \mathrm{Ma}$ ) maximum flooding events are considered more significant (Hardenbol et al., 1998), they may correlate with the maximum flooding events recognized in this study (Fig. 9).

The fact that this transgression is much more clearly manifested in the forearc zones than in the eastern basins suggests that it was reinforced by a tectonically driven subsidence of the forearc zones of northern Peru and Ecuador.

\subsection{Maastrichtian}

An early Maastrichtian transgression is manifested in the forearc zones of northwestern Peru (lower Cenizo Formation) and western Ecuador (Yunguilla Formation), in the Oriente Basin of Ecuador (base of Tena Formation, "Flysch Limón"), and the East-Peruvian Basin (Fundo el Triunfo and Cachiyacu formations; Mourier et al., 1988; Mathalone and Montoya, 1995). The transgression has been identified in most of the eastern areas of Peru (Areniscas de Azúcar, Puquín and upper Vilquechico Formations; Koch and Blissenbach, 1962; Jaillard et al., 1993; Carlotto, 1998), and in Bolivia (El Molino Formation), where it is dated as early Maastrichtian by palaeomagnetism coupled with one radiometric date (72 Ma, Sempéré et al., 1997). However, in many eastern areas, stratigraphic data are not accurate enough to determine 
whether this transgression correlates with the early Maastrichtian transgressions recognized in the forearc zones. In the northern part of the Ecuadorian Subandean zone (Bermejo), however, the Maastrichtian Tena Formation seems to record successive marine transgressions (Faucher et al., 1971; Jaillard, 1997a).

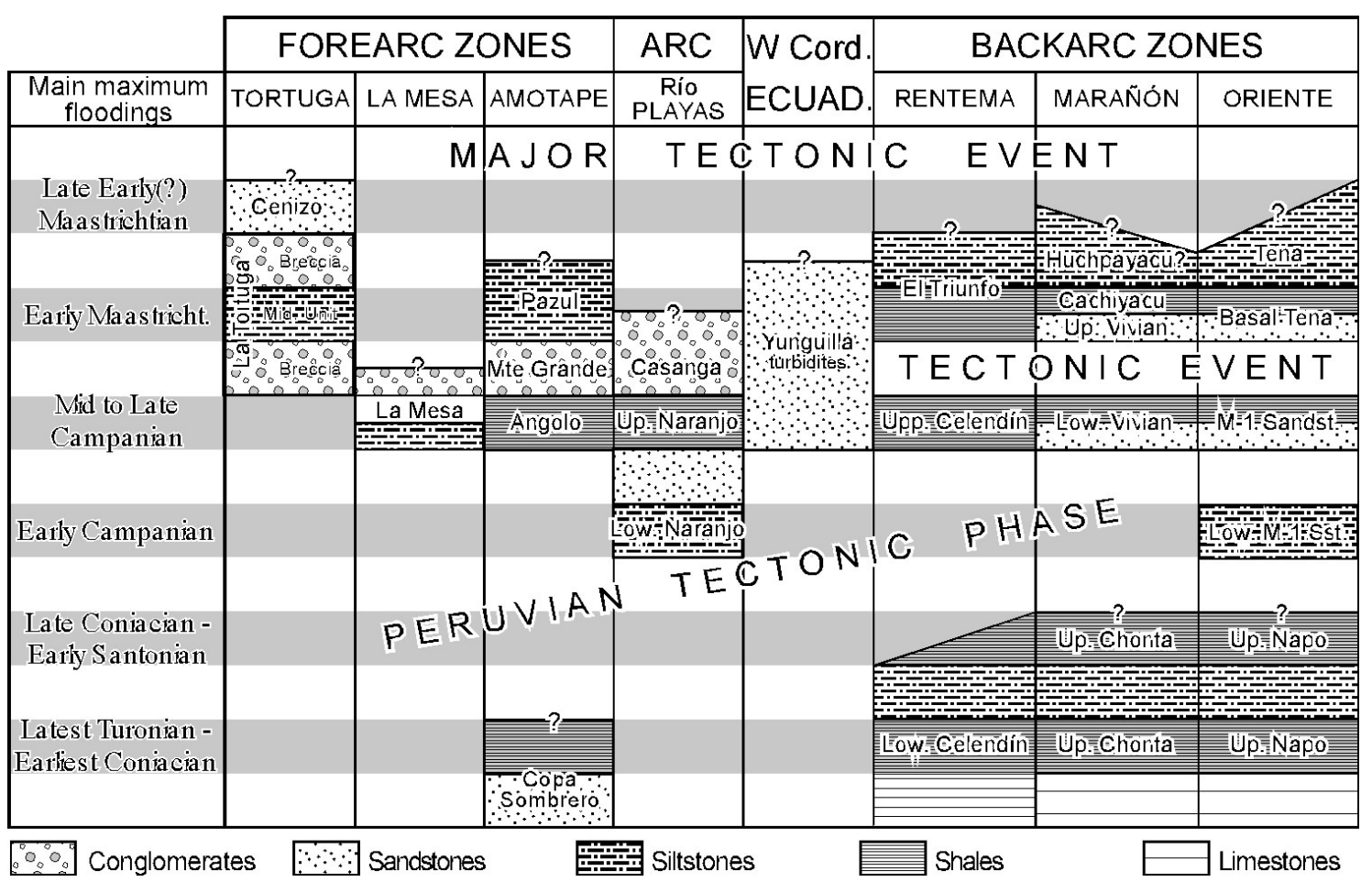

Fig. 10: Tentative correlation of the main maximum flooding events, considered as timelines, across the Andean margin.

Early Maastrichtian transgressions are well known from the Salta (Salfity and Marquillas, 1994), Neuquén (Lagarreta et al., 1989; Barrio, 1990) and Magallanes (Biddle et al., 1986) basins of Argentina (see Malumián and Ramos, 1984; Uliana and Biddle, 1988) and are also well documented in northeastern Colombia (Guerrero and Sarmiento, 1996), Venezuela (Helenes et al., 1998), North America (Gill and Cobban, 1973; Molenaar and Rice, 1989) and on the Pacific guyots, where Arnaud-Vanneau et al. (1995) recognized two maximum flooding events of early Maastrichtian age (sequence boundaries at 73-74 and $71 \mathrm{Ma}$, respectively). These data indicate that the widespread early Maastrichtian maximum flooding event recognized on the Andean margin coincides with a major eustatic rise, which could correspond to the earliest Maastrichtian major maximum flooding event of Haq et al. (1987) (71 Ma according to calibration by Hardenbol et al., 1998; Fig. 9). According to Hardenbol et al. (1998), the early Maastrichtian, major maximum flooding event is younger (ca. 69.5 Ma).

Later Maastrichtian transgressions have been recognized in southern Argentina (Austral and Neuquén basins, e.g. Biddle et al., 1986; Barrio, 1990), in eastern Colombia (Guaduas Formation, Barrio and Coffield, 1992; Guerrero and Sarmiento, 1996), in Venezuela (Helenes and Somoza, 1999) and in southern North America (early late Maastrichtian, Mancini et al., 1996). However, because of poor biostratigraphic control and only local records, correlation between these events is difficult. Hardenbol et al. (1998) mention a significant maximum flooding event during the late early Maastrichtian (69.5 Ma), which might correlate with the late(?) early Maastrichtian upper Cenizo transgression of northwestern Peru.

Conglomerates and turbidites characterize the Maastrichtian deposits of the forearc zones of northern Peru and southern Ecuador. In northwestern Peru, the late Campanian transgressive marls, limestones and sandstones of the upper La Mesa 
Formation grade into shelf sandstones and conglomerates. The late Campanian-early Maastrichtian La Tortuga Formation consists of a 3500-m-thick series of breccias (Olsson, 1944; Bengtson and Jaillard, 1997). In the Celica-Lancones area, the late Campanian beds (Angolo, Zapotillo and El Naranjo formations) are conformably overlain by coarse-grained conglomerates (Monte Grande and Casanga formations, respectively; Olsson, 1934; Baudino, 1995; Jaillard et al., 1996; 1999), in turn overlain by early Maastrichtian deposits (Pazul and Cazaderos formations). In these forearc areas, the lack of younger deposits suggests that they became emergent by middle to late Maastrichtian times. In the Cordillera of Ecuador, the early Maastrichtian is marked by turbiditic deposits (Yunguilla Formation), and no late Maastrichtian beds have been identified. In the backarc basins, the late Maastrichtian is marked either by deposition of fine-grained redbeds or by hiatuses (Jaillard, 1997a).

Such coarse-grained deposits express an important tectonic activity in the forearc zone, which could be related to rapid wrench movements evidenced between 70 and $60 \mathrm{Ma}$ in the arc zone of central and northern Peru (Bussel and Pitcher, 1985). A late Maastrichtian tectonic activity is further documented by a thermal event (75-60 Ma; Litherland et al., 1994) and by a rapid uplift around 65 Ma (Spikings et al., 2001) recorded in the Eastern Cordillera of Ecuador, and by a latest Maastrichtian deformational phase manifested in central Colombia (Cheilletz et al., 1997). They seem to correlate with the accretion of an oceanic terrane known in central Ecuador (Jaillard et al., 2004).

No marine deposits correlating with the major early Danian sea-level rise (Haq et al., 1987; Fig. 9) have been recognized on the Andean margin. However, the poor chronostratigraphic data available for the Paleocene subaerial deposits do not allow to correlate them accurately with the tectonic and sedimentary events recorded in the forearc zones.

\section{Conclusions}

(1) Six maximum flooding events are recognized on the Andean margin of northern Peru and Ecuador (Fig. 10), viz. (1) latest Turonian-early Coniacian, (2) late Coniacian-early Santonian, (3) early Campanian, (4) mid Campanian-early late Campanian, (5) early Maastrichtian and (6) terminal early Maastrichtian. The major marine transgressions occurred in the latest Turonian-early Coniacian, mid Campanianearly late Campanian, and early Maastrichtian, a pattern which coincides broadly with known eustatic sea level rises (Fig. 9).

(2) Although most of the marine transgressions on the Andean margin coincide in time with eustatic sea-level rises, their magnitudes do not correspond to those predicted by the eustatic charts of Haq et al. (1987) and Hardenbol et al. (1998) (Fig. 9). For example, the major mid Campanian-early late Campanian transgression on the Andean margin may correlate with either the mid Campanian (78.5 Ma), or the early late Campanian (74.5 Ma) sea-level rises of Hardenbol et al. (1998), whereas the major latest Santonian-earliest Campanian eustatic transgression (Haq et al., 1987; Hardenbol et al., 1998) has been only locally recorded on the Andean margin. Therefore, regional or local tectonic movements probably account for the absence of traces of the middle Santonian, late Campanian or early Danian sea-level rises on the Andean margin, and for the enhancement of the mid Campanian and early Maastrichtian transgressions.

(3) With respect to the tectonic evolution of the Andean margin, the following results are emphasized :

- Fine-grained clastic sedimentation in the Oriente and East-Peruvian basins began in the mid Turonian-earliest Coniacian (Fig. 10), and is taken as the first manifestation of the "Peruvian" tectonic phase. 
- The Campanian regional transgression in the Peruvian-Ecuadorian forearc zones concealed the "Peruvian" deformational event, which occurred between the late Coniacian and mid Campanian (Fig. 10), most probably during the mid Santonianearliest Campanian interval (ca. 85-82 Ma).

- The "Peruvian" tectonic phase caused a paleogeographic upheaval, indicated by the subsequent development of a NNE-trending forearc basin, which extended at least from Paita to Quito $\left(5^{\circ} 30^{\prime} \mathrm{S}-0^{\circ}\right)$.

- In the forearc zones, only short-lived marine transgressions are recorded in the late Campanian and Maastrichtian, because of a nearly continuous tectonic activity, which seems to culminate in the latest Campanian.

- A widespread, regional late Maastrichtian unconformity suggests that a major tectonic event affected the whole Andean margin at this time (68-65 Ma; Fig. 10).

\section{Acknowledgements}

This paper is an expanded and updated version of the contributions by Jaillard (1997b) and Bengtson and Jaillard (1997) to the Second European Meeting on the Palaeontology and Stratigraphy of South America, Heidelberg 1997. We are indebted to Jean Philip (Marseille) and Didier Néraudeau (Rennes), who assisted in dating some stratigraphic units, to Gérard Laubacher (Montpellier) who contributed significantly to the mapping of the Celica-Lancones area and to Javier Jacay (Lima) for collecting some of the specimens from the Bagua area. We thank Hans Lang (Ludwigshafen) for preparation of the ammonites and Karin Riedelsberger (Universität Heidelberg) for making casts of crucial specimens. IRD (formerly ORSTOM, France) supported most of the field work and transport of samples; costs for the latter were also defrayed by the Universität Heidelberg. This paper benefited from discerning criticism and comments by Annie Arnaud-Vanneau (Université Joseph Fourier, Grenoble) and Frank Wiese (Freie Universität, Berlin).

\section{References}

Arnaud-Vanneau, A., Bergersen, D.B., Camoin, G.F., Ebren, P., Haggerty, J.A., Ogg, J.G., Premoli Silva, I., Vail, P.R., 1995. A model for depositional sequences and systems tracts on small, mid-ocean carbonate platforms: Examples from Wodejebato (sites 873-877) and Limalok (site 871) Guyots. In: Haggerty, J.A., Premoli Silva, I., Rack, F., McNutt, M.K. (Eds.), Proceedings of the Ocean Drilling Program, Scientific results 144, 819-840.

Askin, R.A., Elliot, D.H., Stilwell, J.D., Zinsmeister, W.J., 1991. Stratigraphy of Campanian and Eocene sediments, Cockburn Island, Antarctic Peninsula. Journal of South American Earth Sciences 4, 99117.

Aspden, J.A., Harrison, S.H., Rundle, C.C., 1992. New geochronological control for the tectonomagmatic evolution of the metamorphic basement, Cordillera Real and El Oro Province of Ecuador. Journal of South American Earth Sciences 6, 77-96.

Barrio, C.A., 1990. Paleogeographic controls of Upper Cretaceous tidal deposits, Neuquén Basin, Argentina. Journal of South American Earth Sciences 3, 31-49.

Barrio, C.A., Coffield, D.Q., 1992. Late Cretaceous stratigraphy of the Upper Magdalena Basin in the Payandé-Chaparral segment (western Girardot Sub-Basin), Colombia. Journal of South American Earth Sciences 5, 123-139.

Baudino, R., 1995. Evolution des Andes d'Équateur au Néogène: les enseignements de l'étude des bassins montagneux. Thesis University Pau, 437 p., unpublished.

Benavides-Cáceres, V., 1956. Cretaceous system in northern Peru. Bulletin of the American Museum of Natural History 108, 4, 353-494.

Bengtson, P., 1988. Ammonites. In: T. Mourier et al.: The Upper Cretaceous-Lower Tertiary marine to continental transition in the Bagua Basin, northern Peru: paleontology, biostratigraphy, radiometry, correlations. Newsletters on Stratigraphy 19(3), 154-156.

Bengtson, P., Souza Lima, W., Tröger, K.-A., Koutsoukos, E.A.M., Zucon, M.H., 1996. Campanian ammonites and inoceramids from the Sergipe Basin, Brazil. In: XXXIX Congresso Brasileiro de Geologia, Anais 7, 421-423. Sociedade Brasileira de Geologia, Núcleo Bahia-Sergipe, Salvador.

Bengtson, P., Jaillard, E., 1997. Stratigraphic revision of the Upper Cretaceous of the PeruvianEcuadorian border region: preliminary data and tectonic interpretations. In: T. Bechstaedt, P. Bengtson, R. Greiling, V. Schweizer (Eds.): 18th IAS Regional European Meeting of 
Sedimentology, Heidelberg, September 2-4, 1997, Abstracts 71-72. Gaea heidelbergensis 3.

Biddle, K.T., Uliana, M.A., Mitchum Jr, R.M., Fitzgerald, M.G., Wright, R.C., 1986. The stratigraphic and structural evolution of the Central and Eastern Magallanes Basin, Southern South America. In: P.A. Allen, P. Homewood (Eds.), Foreland basins. International Association of Sedimentologists, Special Publication 8, 41-61, Blackwell, Oxford.

Bristow, C.R., Hoffstetter, R., 1977. Lexique Stratigraphique International, V, 5 a2, Ecuador, 2nd ed. 410 pp. CNRS, Paris.

Bussel, M.A., Pitcher, W.S., 1985. The structural control of batholith emplacement. In: M.P. Pitcher, E.J. Cobbing, R.D. Beckinsale (Eds.), Magmatism at a Plate Edge: the Peruvian Andes, Blackie Halsted Press, London, 167-176.

Carlotto, V., 1998. Évolution andine et raccourcissement au niveau de Cusco (13-16 $\left.{ }^{\circ} \mathrm{S}\right)$, Pérou. Enregistrement sédimentaire, chronologie, contrôles paléogéographiques, évolution cinématique. Thesis Université Grenoble I, 250 p.

Cheilletz, A., Giuliani, G., Branquet, Y., Laumonier, B., Sánchez, A.J., Féraud, G., Arhan, T., 1997. Datation K-Ar et ${ }^{40} \mathrm{Ar} /{ }^{39} \mathrm{Ar}$ à $65 \pm 3 \mathrm{Ma}$ des gisements d'émeraude du district de Chivor-Macanal : argument en faveur d'une déformation précoce dans la Cordillère orientale de Colombie. Comptes Rendus de l'Académie des Sciences, Paris 324, IIa, 369-377.

Courville, P., Odin, G. S., 2001. Les ammonites spiralées du Campanien et du Maastrichtien de Tercis les Bains (Landes, France). In : G.S. Odin (Ed.), The Campanian-Maastrichtian Stage boundary: characterisation at Tercis les Bains (France) and correlation with Europe and other continents, Elsevier, Amsterdam, 529-549. (Developments in Palaeontology and Stratigraphy 19; IUGS Special Publications Series 36.)

Dávila J.J, Ponce de León, V., 1971. La sección del río Inambari en la faja subandina del Perú, y la presencia de sedimentitas de la Formación Cancaniri (Zapla) del Silúrico. Revista Técnica de los Yacimientos Petróleros Fiscales de Bolivia 1, 67-85, La Paz.

Dhondt, A.V., Jaillard, E., in press. Cretaceous bivalves from Ecuador and northern Peru. Journal of South American Earth Sciences, this volume.

Ducloz, C., Rivera, R., 1956. La formación Chonta en la región del rio Cahuapanas, Loreto. Boletín de la Sociedad Geológica del Perú 30, 131-140.

Faucher, B., Vernet, R., Bizon, G., Bizon, J.J., Grekoff, N., Lys, M., Sigal, J., 1971. Sedimentary Formations in Ecuador. A stratigraphic and micropaleontological survey. Bureau d'Études Indust. Cooperation, Institut Français de Pétrole (BEICIP), 220 p., 3 vol.

Fisher, A.G., 1956. Desarollo geológico del Noroeste peruano durante el Mesozóico. Boletín de la Sociedad Geológica del Perú 30, 177-190. Lima.

Gill, J.R., Cobban, W.A., 1973. Stratigraphy and geological history of the Montana Group and equivalent rocks, Montana, Wyoming and North and South Dakota. U.S. Geological Survey Professional Paper 776, 1-37.

Gutierrez, M., 1975. Contribución al conocimiento micropaleontológico del Oriente peruano. Boletín de la Sociedad Geológica del Perú 49, 25-52.

Guerrero, J., Sarmiento, G., 1996. Estratigrafía física, palinológica, sedimentológica y secuencial del Cretácico superior y Paleoceno del piedemonte Llanero. Implicaciones en exploración petrolera. Geología Colombiana 20, 3-66, Bogotá.

Haq, B.U., Hardenbol, J., Vail, P.R., 1987. Chronology of fluctuating sea levels since the Triassic. Science 235, 1156-1167.

Hardenbol, J., Thierry, J., Farley, M.B., Jacquin, T., de Graciansky, P.C., Vail, P.R., 1998. Mesozoic and Cenozoic sequence chronostratigraphic framework of European Basins. SEPM Special Publication $60,3-131$.

Helenes, J., De Guerra, C., Vasquez, J., 1998. Palynology and chronostratigraphy of the Upper Cretaceous in the subsurface of the Barinas area, Western Venezuela. American Association of Petroleum Geologists Bulletin 82, 1308-1328.

Helenes, J., Somoza, D., 1999. Palynology and sequence stratyigraphy of the Cretaceous of eastern Venezuela. Cretaceous Research 20, 447-463.

Hobbs, G.W., 1975. Stratigraphy of Cretaceous and Jurassic systems exposed in the Cutucú mountains. Internal Report, ECUA-141, Petroproducción-Quito, 11 pp.

Hungerbühler, D., 1997. Neogene basins in the Andes of southern Ecuador: evolution, deformation and regional tectonic implications. PhD thesis ETH Zürich, $\mathrm{n}^{\circ} 12371,182$ p., 1 map h.t.

Iddings, A., Olsson, A.A., 1928. Geology of northwest Peru. American Association of Petroleum Geologists Bulletin 12, 1-39.

Jaillard, E., 1994. Kimmeridgian to Paleocene tectonic and geodynamic evolution of the Peruvian (and Ecuadorian) margin. In: J.A. Salfity (Ed.), Cretaceous tectonics in the Andes 101-167, Earth Evolution Sciences, Fried. Vieweg \& Sohn, Braunschweig/Wiesbaden.

Jaillard, E., 1997a. Síntesis estratigráfica y sedimentológica del Cretáceo y Paleógeno de la cuenca oriental del Ecuador. 164 pp., Orstom-Petroproducción, Quito.

Jaillard, E., 1997b. A sedimentary model for the Cretaceous Oriente Basin of Ecuador. In: T. Bechstaedt, P. Bengtson, R. Greiling, V. Schweizer (Eds.): 18th IAS Regional European Meeting of 
Sedimentology, Heidelberg, September 2-4, 1997, Abstracts 175-176. Gaea heidelbergensis 3.

Jaillard, E., Cappetta, H., Ellenberger, P., Feist, M., Grambast-Fessard, N., Lefranc, J.P., Sigé, B., 1993. The Late Cretaceous Vilquechico Group of Southern Peru. Sedimentology, Paleontology, Biostratigraphy, Correlations. Cretaceous Research,14, 623-661.

Jaillard, E., Ordoñez, M., Berrones, G., Bengtson, P., Bonhomme, M., Jiménez, N., Zambrano, I., 1996. Sedimentary and tectonic evolution of the arc zone of southwestern Ecuador during Late Cretaceous and Early Tertiary times. Journal of South American Earth Sciences 9, 131-140.

Jaillard, É., Laubacher, G., Bengtson, P., Dhondt, A., Philip, J., Bulot, L.G., Robert, E., 1998. Revisión estratigráfica del Cretáceo superior del Noroeste peruano y Suroeste ecuatoriano. Datos preliminares y consecuencias tectónicas. Boletin de la Sociedad geológica del Perú 88, 101-115.

Jaillard, E., Laubacher, G., Bengtson, P., Dhondt, A., Bulot, L., 1999. Stratigraphy and evolution of the Cretaceous forearc Celica-Lancones basin of southwestern Ecuador. Journal of South American Earth Sciences 12(1), 51-68.

Jaillard, É., Hérail, G., Monfret, T., Díaz-Martínez, E., Baby, P., Lavenu, A., Dumont, J.-F., 2000. Tectonic evolution of the Andes of Ecuador, Peru, Bolivia and northernmost Chile. in: Cordani, U.G., et al. (Eds.), Tectonic evolution of South America, 481-559, Publ. 31st Int. Geol. Cong., Rio de Janeiro.

Jaillard, E., Ordoñez, O., Suárez, J., Toro, J., Iza, D., Lugo, W., 2004. Stratigraphy of the Late Cretaceous-Paleogene deposits of the Western Cordillera of Central Ecuador: Geodynamic implications. J. South Am. Earth Sci., in press.

Kauffman, E.G. (compiler), Kennedy, W.J., Wood, C.J., 1996. The Coniacian stage and substage boundaries. Bulletin de l'Institut Royal des Sciences Naturelles de Belgique, Sciences de la Terre, 66 suppl., 81-94, Bruxelles.

Kehrer, W., Kehrer, P., 1969. Die oberkretazische San Juan Formation der Westkordillere Ecuadors. Neues Jahrbuch für Geologie und Paläontologie, Abhandlungen 133, 1-22, Stuttgart.

Kennerley, J.B., 1973. Geology of the Loja Province, southern Ecuador. Institute of Geological Sciences, Report 23, 1-34.

Klinger, H.C., Kennedy, W.J., 1980. Cretaceous faunas from Zululand and Natal, South Africa: The ammonite subfamily Texanitinae Collignon, 1948. Annals of the South African Museum 80, 1357.

Kerr, A.C., Aspden, J.A., Tarney, J., Pilatasig, L.F., 2002. The nature and provenance of accreted terranes in Western Ecuador: Geochemical and tectonic constraints. Journal of the Geological Society, London 159, 577-594.

Koch, E., Blissenbach, E., 1962. Las Capas Rojas del Cretáceo superior-Terciario en la región del curso medio del rio Ucayali, Oriente del Perú. Boletín de la Sociedad Geológica del Perú 39, 7-141.

Küchler, T., Odin, G.S., 2001. Upper Campanian-Maastrichtian ammonites (Nostoceratidae, Diplomoceratidae) from Tercis les Bains (Landes, France). In: G.S. Odin (Ed.), The CampanianMaastrichtian Stage boundary: characterisation at Tercis les Bains (France) and correlation with Europe and other continents, 500-528. Elsevier, Amsterdam.

Kummel, B., 1948. Geological reconnaissance of the Contamana region, Peru. Geological Society of America Bulletin 59, 1217-1266.

Lagarreta, L., Kokogián, D.A., Boggetti, D.A., 1989. Depositional sequences of the Malargüe Group (Upper Cretaceous-lower Tertiary), Neuquén Basin, Argentina. Cretaceous Research 10, 337-356.

Litherland, M., Aspden, J.A., Jemielita, R.A., 1994. The metamorphic belts of Ecuador. British Geological Survey, Overseas Memoir 11, 147 pp., 2 maps, Keyworth.

Malumián, N., Ramos, V.A., 1984. Magmatic intervals, transgression-regression cycles and oceanic events in the Cretaceous and Tertiary of southern South America. Earth and Planetary Science Letters 67, 228-237.

Mancini, E.A., Puckett, T.M., Tew, B.H., 1996. Integrated biostratigraphic and sequence stratigraphic framework for Upper Cretaceous strata of the eastern Gulf Coastal Plain, USA. Cretaceous Research 17, 645-669.

Mathalone, J.M.P., Montoya, M., 1995. Petroleum geology of the Sub-andean Basins of Peru. In: A.J. Tankard, R. Suárez, H.J. Welsink (Eds.), Petroleum Basins of South America, American Association of Petroleum Geologists Memoir 62, 423-444.

Michaud, F., Fourcade, E., Azema, J., Carballo Hernandez, M.A., Franco Austin, J.C., 1992. El Cretácico medio y superior de la parte meridional del Bloque Maya (Guatemala). Journal of South American Earth Sciences 5, 229-236.

Mills, S.J., 1972. A review of micropaleontological evidence from the Ecuadorian Oriente. AngloEcuadorian Oilfields Ltd, Ecuadorian Oriente Geological note ${ }^{\circ} 26,21$ pp., PetroproducciónQuito.

Molenaar, C.M., Rice, D.D., 1988. Cretaceous rocks of the Western Interior Basin. The Geology of North America, vol. D-2, Sedimentary Cover, 77-82, Geological Society of America.

Monciardini, C., Fauconnier, D., Manivit, H., 1984. Phosphates d'Equateur : 1ère phase. Etude micropaléontologique et palynologique du sondage "km 81" et de l'affleurement "km 80". Etude SGN/GEO: 84 GEO EM 113, internal report, BRGM, 28 pp., Orléans. 
Mourier, T., Bengtson, P., Bonhomme, M., Buge, E., Cappetta, H., Crochet, J.-Y., Feist, M., Hirsch, K.F., Jaillard, E., Laubacher, G., Lefranc, J.P., Moullade, M., Noblet, C., Pons, D., Rey, J., Sigé, B., Tambareau, Y., Taquet, P., 1988. The Upper Cretaceous-Lower Tertiary marine to continental transition in the Bagua basin, northern Peru. Newsletters on Stratigraphy 19, 143-177.

Müller, H., Aliaga, E., 1981. Estudio bioestratigráfico del Cretáceo de la cuenca Marañon. Petroperu, unpubl. report, 57 pp., Lima.

Muniz, G.C.B., 1993. Novos moluscos da Formação Gramame, Cretáceo Superior dos estados da Paraíba e de Pernambuco, Nordeste do Brasil. Universidade Federal de Pernambuco, Departamento de Geologia, Publição Especial 1, 1-202.

Odin, G.S, Lamaurelle, M.A., 2001. The global Campanian-Maastrichtian stage boundary. Episodes 24, 229-238.

Olsson, A.A., 1934. Contributions to the paleontology of northern Peru: The Cretaceous of the Amotape Region. Bulletins of American Paleontology 20, 69, 1-104.

Olsson, A.A., 1944. Contributions to the paleontology of northern Peru: Part VII. The Cretaceous of the Paita Region. Bulletins of American Paleontology 28, 111, 159-304.

Pérez, E., Reyes, R., 1996. Neobuchitrigonia gen. nov. y Buchotrigonia Dietrich (Bivalvia; Trigoniidae) en el Senoniano de Sudamérica. Revista Geológica de Chile 23, 201-215.

Petersen, G., 1949. Condiciones geográficas y geológicas de la Cuenca del río Zarumilla. Sociedad Geológica del Perú Vol. Jubilar, fasc. 7, 1-40.

Pratt, W.T., Figueroa, J.F., Flores, B.G., 1998. Mapa geológico de la Cordillera Occidental del Ecuador entre $3^{\circ}-4^{\circ} \mathrm{S}$, escala 1/200.000. CODIGEM-Ministerio de Energía y Minas-BGS, Quito.

Raynaud, J.-F., Bouroullec, J., Homewood, P., Villanova, M., 1993. Equateur, Bassin de l'Oriente : Etude palynologique d'un intervalle Crétacé supérieur sur 20 puits. Etude sédimentologique des grès M1. Unpublished report, Elf-Aquitaine Production, 98 pp.

Reyes, L., Caldas, J., 1987. Geología de los cuadrángulos de Las Playas, La Tina, Las Lomas, Ayabaca, San Antonio, Chulucanas, Morropon, Huancabamba, Olmos y Pomahuaca. Boletín del Instituto Geología Minería Metalurgía (A) 39, 83 pp., Lima.

Reyes, L., Vergara, J., 1987. Evaluación geológica y potencial petrolífero de la Cuenca Lancones. Unpublished report, Petroperú, 57 pp., Lima.

Reynaud, C., Jaillard, É., Lapierre, H., Mamberti, M., Mascle, G.H., 1999. Oceanic plateau and island arcs of Southwestern Ecuador: their place in the geodynamic evolution of northwestern South America. Tectonophysics 307, 235-254.

Rivadeneira, M., Dávila, C., Toro, J., 1995. La Arenisca "M-1” en la cuenca ecuatoriana. 1ero Congreso de Petróleo y Medio ambiente, Quito 1995, 15 pp.

Robert, E., 2002. La transgression albienne dans le bassin andin (Pérou) : biostratigraphie, paléontologie (ammonites) et stratigraphie séquentielle. Strata (2) 38, 1-380, Toulouse.

Robertson Research., 1988. Palynofacies analyses of selected core samples from the Conoco Ecuador Limited Daimi-1 and Amo-1 wells, Oriente Basin, Ecuador. Informe interno ECUA-227, 15 pp., Petroproducción-Quito.

Robertson Research, 1990. Palynological zonation of the Oriente Basin. Petroperú, Internal report, Robertson Research, 78-111, Lima.

Robertson Research, 1997. Eden-1 well, Stratigraphy and palaeoenvironments. Occidental Oil and Gas Co. (OXY), proprietary report, 31 pp., Quito.

Rodriguez, A., Chalco, A., 1975. Cuenca Huallaga, Resena geológica y posibilidades petrolíferas. Boletín de la Sociedad Geológica del Perú 45, 187-212.

Rosenzweig, A., 1953. Reconocimiento geológico en el curso medio del rio Huallaga. Boletín de la Sociedad Geológica del Perú 44, 106-127.

Salas, G., 1991. Factores geológicos de control de acumulación de hidrocarburos en las cuencas del Oriente peruano. IV Simposio Bolivariano "Exploración petrolera en las cuencas subandinas”, t. 2, trabajo 29, 15 pp., 14 fig., Asociación Colombiana de Geol. Geofis. Petrol., Bogotá 1991.

Salfity, J.A., Marquillas, R.A., 1994. Tectonic and sedimentary evolution of the Cretaceous-Eocene Salta Group Basin, Argentina. In: J.A. Salfity (Ed.), Cretaceous tectonics in the Andes 266-315, Earth Evolution Sciences, Fried. Vieweg \& Sohn, Braunschweig/Wiesbaden.

Sempéré, T., 1994. Kimmeridgian (?) to Paleocene tectonic evolution of Bolivia. In: J.A. Salfity (Ed.), Cretaceous tectonics in the Andes 168-212, Earth Evolution Sciences, Fried. Vieweg \& Sohn, Braunschweig/Wiesbaden.

Sempéré, T., Butler, R.F., Richards, D.R., Marshall, L.G., Sharp, W., Swisher III, C.C., 1997. Stratigraphy and chronology of Upper Cretaceous-Lower Paleogene strata in Bolivia and northwest Argentina. Geological Society of America Bulletin 109, 709-726.

Sigal, J., 1969. Quelques acquisitions récentes concernant la chrono-stratigraphie des formations sédimentaires de l'Équateur. Revista Española de Micropaleontología 1, 205-236,

Soto, V., 1982. Informe estratigráfico de la sección del Pongo de Mainique. Unpublished report, Petroperú, Lima.

Spikings, R.A., Winkler, W., Seward, D., Handler, R., 2001. Along-strike variations in the thermal and tectonic response of the continental Ecuadorian Andes to the collision with heterogeneous oceanic 
crust. Earth and Planetary Science Letters 186, 57-73.

Steinmann, G., 1929. Geologie von Peru. Carl Winters Universitätsbuchhandlung, Heidelberg, 448 p.

Thalmann, H.E., 1946. Micropaleontology of Upper Cretaceous and Paleocene in western Ecuador. American Association of Petroleum Geologists Bulletin 30, 337-347.

Tschopp, H.J., 1953. Oil explorations in the Oriente of Ecuador. American Association of Petroleum Geologists Bulletin 37, 2303-2347.

Uliana, M.A., Biddle, K.T., 1988. Mesozoic-Cenozoic paleogeographic and geodynamic evolution of southern South America. Revista Brasileira de Geociências 18, 172-190.

Vargas, J.M., 1988. Potencial petrolífero de la cuenca Huallaga, Oriente peruano. 3er Simposio Bolivariano, Caracas 1988, 195-225.

Vergara, L., 1997. Stratigraphy, foraminiferal assemblages and paleoenvironments in the Late Cretaceous of the Upper Magdalena Valley, Colombia. Journal of South American Earth Sciences 10, 111132.

Vicente, J.-C., 1981. Elementos de la estratigrafía mesozóica sur-peruana. In: W. Volkheimer, E. Musacchio (Eds.), Cuencas sedimentarias del Jurásico y Cretácico de América del Sur 1, 319-351, Buenos-Aires.

Walaszczyk, I., Cobban, W.A., Harries, P.J., 2001. Inoceramids and inoceramid biostratigraphy of the Campanian and Maastrichtian of the United States Western Interior Basin. Revue de Paléobiologie 20, 1, 117-234.

Walaszczyk, I., Cobban, W.A., Odin, G.S., 2002a. The inoceramid succession across the CampanianMaastrichtian boundary. Bulletin of the Geological Society of Denmark 49, 53-60.

Walaszczyk, I., Odin, G.S., Dhondt, A.V., 2002b. Inoceramids from the upper Campanian and lower Maastrichtian of the Tercis section (SW France), the Global Stratotype Section and Point for the Campanian-Maastrichtian boundary; taxonomy, biostratigraphy and correlation potential. Acta Geologica Polonica 52, 3, 269-305.

Weiss, L., 1955. Planktonic index foraminifera of northwestern Perú. Micropaleontology 1, 301-319.

Whittaker, J.E., Hodgkinson, R.L., 1979. Micropaleontological report on the Napo Formation, eastern Ecuador. British Museum (Natural History), Report OGS n 1979/1, 4 pp.

Wilson, J.J., 1963. Cretaceous stratigraphy of central Andes of Peru. American Association of Petroleum Geologists Bulletin 47, 1-34.

Wright, C.W. 1996. Cretaceous Ammonoidea. In: R.L. Kaesler (Ed.). Treatise on Invertebrate Paleontology, Part L. Mollusca 4 (revised), 4, 1-362. Geological Society of America; University of Kansas, Lawrence.

Zegarra, J.S., 1964. Geología del flanco Nor-Este de la Cordillera oriental de los Andes peruanos considerando la formación Chonta en particular (región de Campanquiz-Pongo de MansericheYurimaguas). Unpublished BSc thesis, Universidad Nacional Mayor de San Marcos, Lima. 